\title{
Thirty thousand years of vegetation development and climate change in Angola (Ocean Drilling Program Site 1078)
}

\author{
L. M. Dupont ${ }^{1}$, H. Behling ${ }^{2}$, and J.-H. Kim ${ }^{3}$ \\ ${ }^{1}$ MARUM - Center for Marine Environmental Sciences, University of Bremen, Bremen, Germany \\ ${ }^{2}$ Palynology and Climate Dynamics, Albrecht-von-Haller-Inst. for Plant Sciences, Univ. of Göttingen, Göttingen, Germany \\ ${ }^{3}$ NIOZ, Texel, The Netherlands
}

Received: 13 December 2007 - Published in Clim. Past Discuss.: 31 January 2008

Revised: 7 May 2008 - Accepted: 22 May 2008 - Published: 10 June 2008

\begin{abstract}
ODP Site 1078 situated under the coast of Angola provides the first record of the vegetation history for Angola. The upper $11 \mathrm{~m}$ of the core covers the past 30 thousand years, which has been analysed palynologically in decadal to centennial resolution. Alkenone sea surface temperature estimates were analysed in centennial resolution. We studied sea surface temperatures and vegetation development during full glacial, deglacial, and interglacial conditions. During the glacial the vegetation in Angola was very open consisting of grass and heath lands, deserts and semi-deserts, which suggests a cool and dry climate. A change to warmer and more humid conditions is indicated by forest expansion starting in step with the earliest temperature rise in Antarctica, 22 thousand years ago. We infer that around the period of Heinrich Event 1, a northward excursion of the Angola Benguela Front and the Congo Air Boundary resulted in cool sea surface temperatures but rain forest remained present in the northern lowlands of Angola. Rain forest and dry forest area increase 15 thousand years ago. During the Holocene, dry forests and Miombo woodlands expanded. Also in Angola globally recognised climate changes at 8 thousand and 4 thousand years ago had an impact on the vegetation. During the past 2 thousand years, savannah vegetation became dominant.
\end{abstract}

\section{Introduction}

The climate of tropical Africa is strongly coupled to the position of the Intertropical Convergence Zone (ITCZ) and its southern African branch, the Congo Air Boundary (CAB)

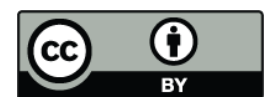

Correspondence to: L. Dupont

(dupont@uni-bremen.de)
(Leroux, 1983; Tyson, 1986). Shifts in the latitudinal position of the ITCZ have been associated with the climate variability in the Sahara and Sahel, but much less is known about the connections with the climate in southern Africa (e.g. Nicholson, 2000). Our knowledge mainly comes from studies on east African lakes, which focus on the climate of East Africa and the Rift Mountains (e.g. Vincens et al., 2005, 2007; Bonnefille and Chalié, 2000; Johnson et al., 2004). They are, therefore, less suitable to monitor the effects of ITCZ and $\mathrm{CAB}$ variability on climate and vegetation of west southern Africa.

Recording and understanding climate change in southern Africa is important because it opens a window to study the variability of both tropical and subtropical climate systems of the Southern Hemisphere. How does the Atlantic monsoon in Angola change from glacial to interglacial? Does it have Northern or Southern Hemisphere timing? How much is the precipitation in Angola influenced by East Atlantic sea surface temperatures? What is the impact of changes in the Atlantic meridional overturning circulation?

The latitudinal position of the $\mathrm{CAB}$ is connected with the amount of rainfall and the duration of the rainy season. The land-ocean temperature contrast is associated with aridity, wind strength and wind direction. Both directly affect the vegetation. Earlier studies have shown that vegetation changes in Angola are sensitively recorded by pollen and spores in marine sediments along the coast (Shi and Dupont, 1997; Dupont and Behling, 2006). The marine material allows us to compare the pollen record with the sea surface temperature (SST) record from the same core and thus enabling us a direct land-sea correlation.

We studied a high resolution marine core (ODP Hole 1078C) spanning the past $30 \mathrm{ka}$ encompassing the Last Glacial Maximum, Deglaciation including Heinrich Event 1

Published by Copernicus Publications on behalf of the European Geosciences Union. 

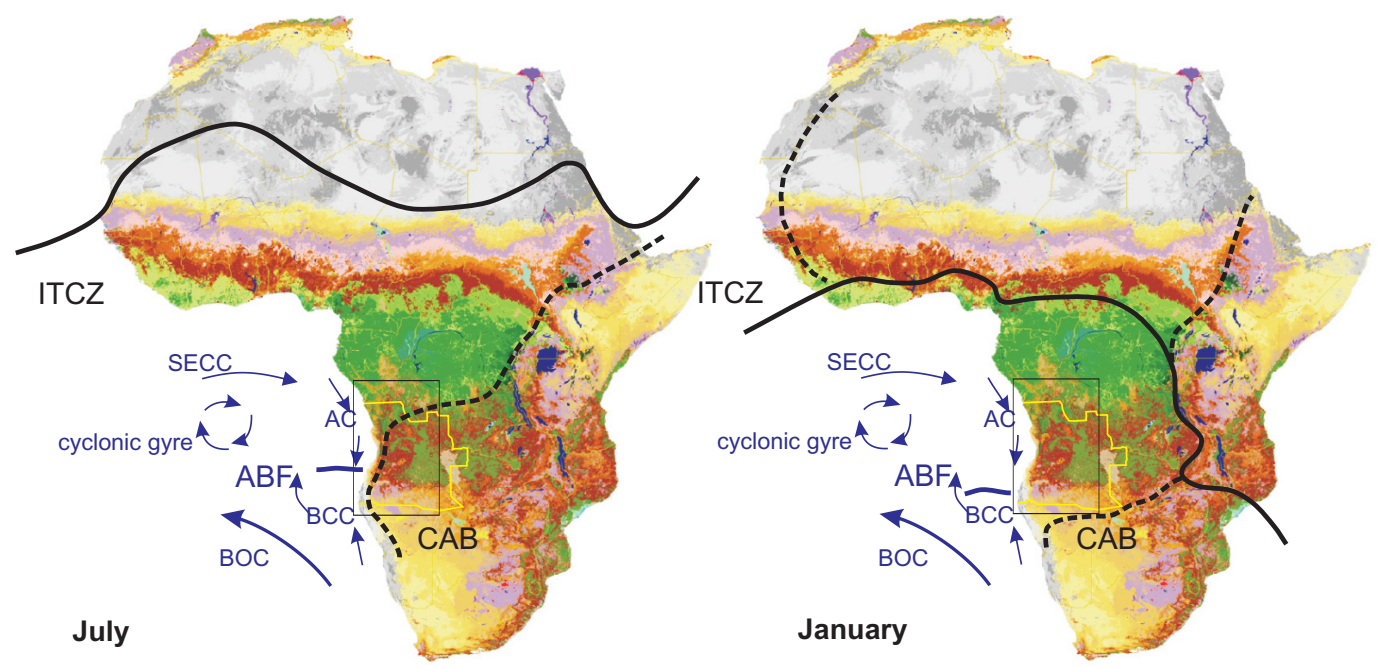

Fig. 1. Landcover of Africa (Bartholome et al., 2002), ocean surface currents of the eastern South Atlantic (Shannon and Nelsson, 1996), and summer and winter position of important tropical frontal systems (Leroux, 1983). ITCZ, Intertropical Convergence Zone; CAB, Congo Air Boundary; ABF, Angola Benguela Front; SECC, South equatorial Counter Current; AC, Angola Current; BCC, Benguela Coastal Current; BOC, Benguela Ocean Current. Boundary of the state Angola in yellow. Boxes denote the detail shown in Fig. 2. Note that the extension of the tropical rain forest (light to dark green) is associated with humid conditions all year round occurring between the southernmost position of the ITCZ in January and the northernmost position of the CAB in July.

and the Younger Dryas period, and the Holocene. We aim to interpret fluctuations in the pollen assemblage in terms of vegetation change on the continent taking into account effects of transport of pollen by wind and rivers. The thus reconstructed vegetation variability is compared to other African environmental records. We aim at a conceptual model of shifts in the latitudinal position of atmospheric and marine fronts explaining environmental changes in Angola that might be tested with numerical models.

\section{Regional climate and ocean circulation and its impact on the modern vegetation of west southern Africa}

Present-day climate in Angola ranges from the permanently wet climate of the Congo basin in the north to the dry summer rain climates in the south. The Atlantic or west African monsoon controls the climate of the northernmost part during most of the year, while the middle and southern parts receive (Atlantic) moisture only during austral summer. Angola is the southernmost region where the West African monsoon brings rain (Fig. 1). The boundary is in the form of a low pressure area, the CAB (formerly Zaire Air Boundary), that annually migrates over Angola from its southern surface position around $20-15^{\circ} \mathrm{S}$ in January (austral summer) to its northern position around $9-6^{\circ} \mathrm{S}$ in July (austral winter) (Leroux, 1983). The CAB is part of the discontinuities that divide easterly trades and westerly monsoonal wind systems over Africa and can be regarded as a southern branch of the ITCZ. The latitudinal position and annual migration of these systems determines the timing and duration of the rainfall seasons. They are associated with the global thermal gradient and the strength and position of the Hadley Cell (Nicholson, 2000). However, sea surface temperatures and ocean circulation also have an impact on the position of the ITCZ.

The surface and shallow subsurface ocean circulation in the eastern Angola Basin is dominated by the South Atlantic cyclonic gyre consisting of the Benguela Ocean Current flowing northwards and westwards over the Walvis Ridge, the South Equatorial Counter Current flowing eastwards, and the Angola Current flowing southwards along the coast (Fig. 1). In the marine realm, as in the terrestrial one, an important frontal system exists off the coast of Angola in the form of the Angola Benguela Front (ABF) annually migrating between 17 and $14^{\circ} \mathrm{S}$. South of the ABF, the surface Benguela Coastal Current being a tongue of the Benguela Ocean Current flows northwards along the coast. North of the ABF, the Angola Current flows southwards and the Benguela Coastal Current can be traced as a shallow subsurface current up to $5^{\circ} \mathrm{S}$ (Peterson and Stramma, 1991; Schneider et al., 1995, 1997).

The $\mathrm{ABF}$ is recognizable by a sea surface temperature (SST) gradient of $4^{\circ} \mathrm{C}$ per $1^{\circ}$ of latitude and identifiable to a depth of at least $200 \mathrm{~m}$. The front is most intense within $250 \mathrm{~km}$ from the coast. The position and the strength of the front are maintained through a combination of factors including coastal orientation, wind stress, and opposing flows of the equatorward Benguela Coastal Current and the poleward Angola Current (Shannon and Nelson, 1996). Within the limits 
of the coastal orientation, there is a coupling between the position of the $\mathrm{ABF}$ and the $\mathrm{CAB}$ on land. South of the front the zonal component of the wind stress over the ocean is east (SE trades) and north of the front the zonal component is west (SW monsoon). Strong SE trade winds will trigger both a cooling south of the $\mathrm{ABF}$ by increasing the upwelling along the coast and a warming north of the ABF due to stronger intrusion of warm equatorial waters by the Angola Current (Kim et al., 2003). Intense coastal upwelling occurs only south of the ABF, whereas directly north of it upwelling is seasonal and relatively weak (Wefer et al., 1998).

The position of the climatic and oceanic frontal systems is reflected in the vegetation of southern Africa. The southern boundary of the Congolian rain forest corresponds to the latitudinal July (austral winter) position of the CAB. The Zambezian phytogeographical region is extended in Angola consisting of different types of dry forest, woodland, savannah and edaphic grassland (Fig. 2: White, 1983). In the north of Angola the transition between the Zambezian and the Congolian vegetation zones nowadays is mainly occupied by secondary grassland and savannahs. However, surviving cloud forests of Congolian affinity exist occurring at altitudes between 350 and $1000 \mathrm{~m}$. Along the west coast, climate and vegetation are strongly influenced by the SST. Especially, the low SSTs of the upwelling area south of the ABF suppress coastal rain fall (Nicholson and Entekabi, 1987). As a result, the vegetation along the Angolan coast south of $15^{\circ} \mathrm{S}$ has affinities with the Namib Desert (desert of the Moçamedes) and south of $11^{\circ} \mathrm{S}$ with the Karoo-Namib shrubland (White, 1983).

The vegetation of Angola forms the transition between the tropical lowland rain forest of the Congo and the dry savannahs and deserts of the Kalahari and Namibia (Fig. 2). Its development is sensitive to climate change and shifts of the frontal systems described above. In this paper, we present a detailed pollen record of marine sediments of ODP Hole $1078 \mathrm{C}$, which allows the study of the vegetation history of the past $30 \mathrm{ka}$ during full glacial, deglacial, and interglacial conditions.

\section{Material and methods}

The material used is sediment from the upper $11 \mathrm{~m}$ ODP Site 1078 Hole C. The site is located outside the Bight of Angola at $11^{\circ} 55^{\prime} \mathrm{S}, 13^{\circ} 24^{\prime} \mathrm{E}$ in $426 \mathrm{~m}$ deep water. The sediments are composed predominantly of a moderately bioturbated olive-gray silty clay with varying amounts of nannofossils and foraminifers (Wefer et al., 1998).

The age model is established after radiocarbon AMS measurements on foraminifer tests and molluscs carried out at the Leibniz-Laboratory, University of Kiel, Germany (Kim et al., 2003; Rühlemann et al., 2004). Extension of the age model uses eight dates (Table 1: S. Mulitza, personal communication, 2007) calibrated after Fairbanks et al. (2005) us-
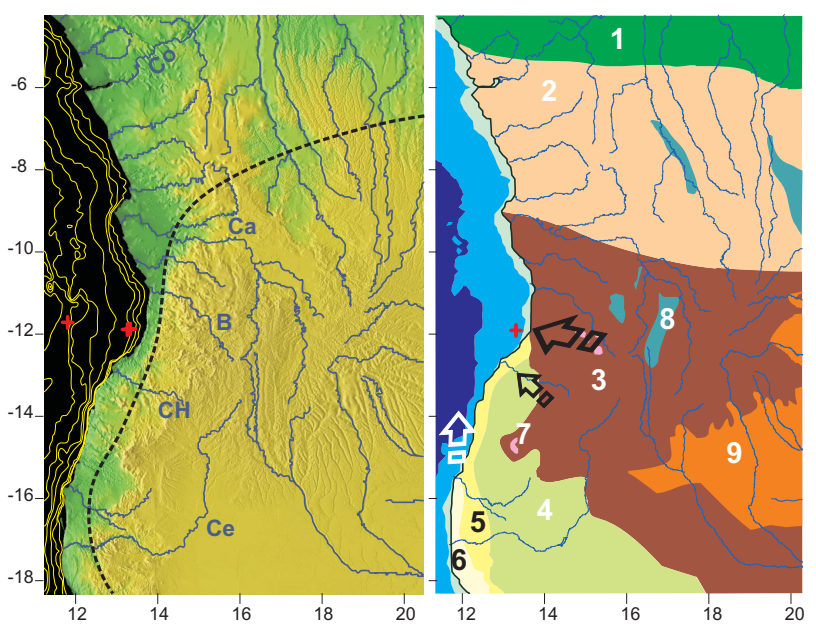

Fig. 2. Left, topography, bathemetry, and major rivers of the study area. Topography after GLOBE http://www.ngdc.noaa.gov/mgg/ topo/globe.html (Hastings and Dunbar, 1998). Bathymetric contours of 100, 200, 500, 1500, 2000, 2500, 3000, and $3500 \mathrm{~m}$ are shown. Red crosses give the locations from left to right of GeoB 1016 and ODP Sites 1079/1078, respectively. Major rivers in blue, Congo River (Co), Cuanza River (Ca), Balombo River (B), Cuhal da Hanha $(\mathrm{CH})$, and Cunene River $(\mathrm{Ce})$. The Balombo River probably is the more important provider of terrestrial input to the coring site, because marine surface currents flow southwards along the Angolan coast. Dashed line denotes the average July (austral winter) position of the Congo Air Boundary (Leroux, 1983). Right, major rivers, predominant offshore wind directions, and simplified phytogeography after White (1983). 1 (dark green), Congolian rain forest; 2 (light brown), transition between Congolian forest and Zambezian savannah and forest; 3 (dark brown), Zambezian dry forest and savannah; 4 (light green), Mopane savannah; 5 (yellow), Nama Karoo semi-desert; 6 (white), Namib desert; 7 (pink), Afromontane forest; 8 (blue green), edaphic grassland; 9 (orange), Damdo woodland. Black arrows show the predominant wind direction to the study site during fall and winter; white arrow shows the predominant wind direction during spring (simplified after Dupont and Wyputta, 2003). During summer and partly during spring, wind is blowing mostly from the ocean and does not bring pollen. Water depths between 0-130 m, 130-2000 m, and 2000-4000 m are distinguished by different shades of blue. Red cross denotes the position of ODP Site 1078 .

ing a marine reservoir effect of 400 years $(\Delta R=0)$. All ages are expressed in 1000 years calibrated BP abbreviated as ka. Dates at 10.71 and $10.21 \mathrm{~m}$ below sea floor (mbsf) have been discarded, because the shell fragments might have been displaced to lower levels by burrowing.

Preparation of palynological samples follows standard procedures. In brief, $3-4 \mathrm{~cm}^{3}$ sediment was decalcified with diluted HCL (ca. 1\%) and treated with HF (ca. 40\%) for several days to remove silicates. Samples were sieved over an $8 \mu \mathrm{m}$ mesh using ultrasonic sieving removing particles smaller than 10-12 $\mu \mathrm{m}$. Pollen samples were mounted in glycerine jelly, microscopically examined by $\mathrm{H}$. Behling 
Table 1. AMS radiocarbon dates of ODP Site 1078C below $9.80 \mathrm{mbsf}$ (S. Mulitza, personal communication 2007). Calibration using R=400 after Fairbanks et al. (2005).

\begin{tabular}{llllllll}
\hline Lab. No & Core/Section & Interval (cm) & Depth (mbsf) & Material & ${ }^{14}$ C age (a) & Error & $\begin{array}{l}\text { Calibrated } \\
\text { age range (a) }\end{array}$ \\
\hline KIA13030 & 2 H-3 & $20-22$ & 9.91 & fract. mollusk & 21340 & $+220 /-210$ & $24799-25415$ \\
KIA13008 & 2 H-3 & $30-32$ & 10.01 & fract. mollusk & 22780 & $+260 /-250$ & $26586-27146$ \\
KIA13028* & 2H-3 & $50-52$ & 10.21 & fract. mollusk & 16960 & $+/-130$ & $19522-19838$ \\
KIA13027* & 2H-3 & $100-102$ & 10.71 & fract. mollusk & 22850 & $+260 /-250$ & $26661-27220$ \\
KIA13023 & $2 \mathrm{H}-4$ & $70-72$ & 11.91 & fract. mollusk & 30250 & $+630 /-590$ & $34282-35567$ \\
KIA13038 & 2H-5 & $60-62$ & 13.31 & fract. mollusk & 33880 & $+1010 /-890$ & $37357-39780$ \\
KIA13007 & 2H-5 & $130-132$ & 14.01 & Nacariua wolfi (snail) & 36780 & $+1560 /-1300$ & $40444-42791$ \\
KIA13006 & 2H-CC & $17-19$ & 16.48 & planktic forams & 44850 & $+5190 /-3130$ & $>45000$ \\
\hline
\end{tabular}

* dates not used in the age model

and L. M. Dupont. Pollen grains were identified using several publications (Ybert, 1979; Bonnefille and Riollet, 1980; Köhler and Brückner, 1982; Sowunmi, 1973, 1995), the African Pollen Database http://medias.obs-mip.fr/ pollen/, and a reference collection. Samples are counted routinely up to 300 pollen grains (without fern spores). However, some samples turned out to be too poor to reach that goal: five samples have a sum of total pollen between 150 and 200 (at 3.8, 20.6, 22.0, 30.0, and 31.7 ka), two samples between 100 and 150 (at 4.0 and $19.9 \mathrm{ka}$ ). These samples neither show exceptionally low diversity nor domination of a single taxon. Charcoal particles have been counted from the pollen slides. Percentages are expressed on the total number of pollen and fern spores, which is denoted in Fig. 5.

Detailed information on analytical techniques used for the determination of long-chain alkenones can be found in the study by Kim et al. (2002). We calculated the alkenone unsaturation index from $U_{37}^{\mathrm{K}^{\prime}}=\left[\mathrm{C}_{37: 2}\right] /\left(\left[\mathrm{C}_{37: 2}\right]+\left[\mathrm{C}_{37: 3}\right]\right)$, where $\mathrm{C}_{37: 2}$ and $\mathrm{C}_{37: 3}$ represent the di- and triunsaturated $\mathrm{C}_{37}$ alkenones, respectively (Prahl and Wakeham, 1987). The $U_{37}^{K^{\prime}}$ values were converted into temperature values applying the culture calibration $U_{37}^{K^{\prime}}=0.034 * T+0.039$ by Prahl et al. (1988), which has also been validated by core-top compilations (Müller et al., 1998). The precision of the measurements $( \pm 1 \sigma)$ was better than $0.003 U_{37}^{K^{\prime}}$ units (or $0.1^{\circ} \mathrm{C}$ ), based on replicate extractions on different days of two laboratory internal reference sediments (CC 2107-3 and CC 1706-2) from the South Atlantic.

\section{Age model and sedimentation rates}

The age depth model is shown in Fig. 3. The upper $9.80 \mathrm{~m}(0-22 \mathrm{ka})$ has been dated by Kim et al. (2003) and Rühlemann et al. (2004). This age model uses the calibration of Calib and the marine calibration curve (Stuiver and Reimer, 1993; Hughen et al., 2004). The lower dates (Ta- ble 2: S. Mulitza, personal communication, 2007) are outside the range of the marine calibration curve and have been calibrated using Fairbanks et al. (2005). Except for the lowermost date, the material consisted out of mollusc shell fragments. Some radiocarbon ages seem to occur at different levels, which can be explained by burrowing down of the molluscs. We therefore consequently chose the upper ones to include in the age model. Calibration ranges increase with age and the uncertainty of the calibration.

For the calibration of the radiocarbon dates, we have applied a reservoir effect of 400 years as suggested by the present day marine reservoir correction database (Butzin et al., 2005). Although there are no direct measurements in the vicinity of ODP Site 1078, we think this is justifiable because the site is just outside the coastal upwelling range and the influence of the open ocean is more pronounced than at sites north or south of it (Wefer et al., 1998). Simulations for the glacial ocean indicate an increase in the surface reservoir age to maximal 600 years (Butzin et al., 2005). An extra shift of 200 years in the glacial dates would not significantly change our age model.

The sedimentation rates for ODP Site 1078 that result from linear interpolation between the calibrated radiocarbon ages are also given in Fig. 3. Until 27 ka sedimentation rates range between 22 and $35 \mathrm{~cm} / \mathrm{ka}$, but are rather imprecise. Between 10-9.8 mbsf (27-22 ka) sedimentation rates drop to low values of about $4 \mathrm{~cm} / \mathrm{ka}$. This estimate is supported by three ages, if we reject the datum's at lower levels (see above). Moreover, a concentration of shells and molluscs have been found at those levels both in Hole $\mathrm{C}$, used in this study, and in the neighbouring Hole B (Wefer et al., 1998). The very low sedimentation might have occurred during the last glacial lowest sea-level period. This seems to be much too early, but a recent publication provided evidence that the period of lowest sea-level must have occurred between 26 and $21 \mathrm{ka}$ ago (Peltier and Fairbanks, 2006). 
Table 2. Percentage mean and standard deviation per zone for selected pollen taxa and groups (listed in the appendix) and ordered after the earliest maximum occurrence. "LGM" period of lowest sea level at the site (see Sect. 4); el. = elements.

\begin{tabular}{|c|c|c|c|c|c|c|c|c|c|c|c|c|c|c|c|c|}
\hline \multirow[b]{2}{*}{ Pollen zone } & \multicolumn{6}{|c|}{ Holocene } & \multicolumn{4}{|c|}{ Deglaciation } & \multicolumn{6}{|c|}{ Glacial } \\
\hline & \multicolumn{2}{|c|}{7} & \multicolumn{2}{|c|}{6} & \multicolumn{2}{|c|}{5} & \multicolumn{2}{|c|}{4} & \multicolumn{2}{|c|}{3} & \multicolumn{2}{|c|}{2} & \multicolumn{2}{|c|}{1} & \multicolumn{2}{|c|}{ "LGM" } \\
\hline $\begin{array}{l}\text { upper } \\
\text { boundary (m) }\end{array}$ & \multicolumn{2}{|c|}{0.00} & \multicolumn{2}{|c|}{1.50} & \multicolumn{2}{|c|}{2.80} & \multicolumn{2}{|c|}{4.20} & \multicolumn{2}{|c|}{8.02} & \multicolumn{2}{|c|}{8.80} & \multicolumn{2}{|c|}{9.70} & \multicolumn{2}{|c|}{$9.81-9.99$} \\
\hline $\begin{array}{l}\text { upper } \\
\text { boundary (ka) }\end{array}$ & \multicolumn{2}{|c|}{ top } & \multicolumn{2}{|c|}{3.7} & \multicolumn{2}{|c|}{7.8} & \multicolumn{2}{|c|}{10.0} & \multicolumn{2}{|c|}{15.4} & \multicolumn{2}{|c|}{18.8} & & & 22.4 & 26.3 \\
\hline Pollen taxon & mean & stdev & mean & stdev & mean & stdev & mean & stdev & mean & stdev & mean & stdev & mean & stdev & mean & stdev \\
\hline Mountain el. & 1.1 & 0.7 & 0.8 & 0.6 & 1.5 & 0.8 & 2.6 & 1.0 & 2.8 & 1.7 & 4.2 & 1.4 & 7.4 & 1.5 & 5.9 & 1.6 \\
\hline Ericaceae & 0.2 & 0.3 & 0.6 & 0.6 & 0.6 & 0.4 & 0.9 & 0.7 & 1.4 & 1.1 & 2.2 & 1.1 & 5.4 & 1.4 & 4.3 & 1.1 \\
\hline Phaeoceros & 0.2 & 0.3 & 0.4 & 0.3 & 0.5 & 0.4 & 0.6 & 0.6 & 2.1 & 1.2 & 2.8 & 1.3 & 3.0 & 0.9 & 3.0 & 1.0 \\
\hline Brachystegia & 0.9 & 0.6 & 5.1 & 2.0 & 1.9 & 0.9 & 1.5 & 0.9 & 0.8 & 0.6 & 1.0 & 0.6 & 1.5 & 0.9 & 1.4 & 0.9 \\
\hline Desert el. & 3.0 & 1.0 & 2.4 & 1.0 & 2.0 & 0.9 & 3.7 & 1.6 & 6.4 & 1.9 & 7.6 & 1.6 & 8.3 & 1.6 & 9.5 & 1.1 \\
\hline Asteroideae & 1.1 & 0.5 & 0.7 & 0.4 & 0.6 & 0.4 & 1.6 & 0.8 & 2.6 & 1.2 & 3.3 & 1.1 & 4.0 & 1.2 & 4.5 & 1.4 \\
\hline Poaceae & 38.2 & 12.5 & 9.6 & 1.5 & 17.1 & 3.3 & 25.6 & 3.8 & 26.5 & 7.0 & 31.7 & 6.7 & 35.2 & 3.6 & 33.2 & 2.6 \\
\hline Cyperaceae & 12.9 & 2.6 & 5.6 & 1.1 & 8.4 & 2.1 & 5.6 & 1.9 & 8.2 & 2.8 & 10.0 & 2.3 & 9.2 & 2.5 & 10.2 & 3.4 \\
\hline Rhizophora & 2.7 & 1.4 & 0.6 & 0.6 & 6.0 & 2.3 & 3.2 & 1.3 & 1.5 & 1.0 & 0.9 & 0.7 & 0.1 & 0.2 & 0.1 & 0.2 \\
\hline Rainforest el. & 4.5 & 1.2 & 2.3 & 1.0 & 3.5 & 1.3 & 3.9 & 1.7 & 2.8 & 1.1 & 3.1 & 1.2 & 1.6 & 0.7 & 1.7 & 0.8 \\
\hline Mallotus-type & 0.7 & 0.6 & 0.4 & 0.3 & 0.6 & 0.5 & 2.5 & 1.7 & 1.5 & 0.9 & 1.6 & 1.0 & 0.3 & 0.4 & 0.6 & 0.7 \\
\hline Myrica & 0.2 & 0.3 & 0.0 & 0.1 & 0.3 & 0.2 & 0.5 & 0.3 & 0.8 & 0.6 & 1.2 & 0.6 & 0.8 & 0.5 & 0.9 & 0.4 \\
\hline Podocarpus & 13.2 & 10.0 & 40.9 & 4.1 & 28.3 & 3.7 & 33.0 & 4.8 & 33.1 & 11.5 & 22.0 & 5.7 & 14.8 & 3.0 & 16.7 & 2.6 \\
\hline Burkea-type & 1.4 & 1.0 & 0.4 & 0.4 & 1.2 & 0.7 & 0.7 & 0.6 & 0.2 & 0.2 & 0.2 & 0.2 & 0.1 & 0.2 & 0.1 & 0.2 \\
\hline Combretaceae & 0.6 & 0.5 & 0.3 & 0.3 & 0.5 & 0.4 & 0.6 & 0.4 & 0.1 & 0.2 & 0.1 & 0.2 & 0.2 & 0.3 & 0.2 & 0.2 \\
\hline Miombo el. & 2.8 & 1.3 & 8.8 & 2.3 & 5.1 & 1.8 & 3.2 & 1.5 & 1.7 & 1.0 & 1.7 & 1.1 & 2.2 & 0.9 & 2.0 & 0.8 \\
\hline Uapaca & 1.2 & 0.7 & 1.7 & 1.3 & 2.4 & 0.8 & 1.3 & 0.7 & 0.3 & 0.4 & 0.1 & 0.2 & 0.2 & 0.2 & 0.1 & 0.1 \\
\hline Alchornea & 1.9 & 1.0 & 0.6 & 0.5 & 1.1 & 0.7 & 0.3 & 0.3 & 0.1 & 0.2 & 0.1 & 0.2 & 0.1 & 0.2 & 0.2 & 0.4 \\
\hline Dry forest el. & 7.6 & 1.8 & 5.7 & 2.3 & 5.7 & 1.8 & 3.4 & 1.3 & 2.8 & 1.1 & 2.9 & 1.1 & 3.1 & 1.3 & 3.9 & 1.2 \\
\hline Tarchonanthus & 1.4 & 1.0 & 0.1 & 0.2 & 1.0 & 0.8 & 0.0 & 0.1 & 0.1 & 0.2 & 0.1 & 0.2 & 0.2 & 0.3 & 0.2 & 0.3 \\
\hline $\begin{array}{l}\text { Artemista ajra } \\
\text { Afzelia }\end{array}$ & 0.5 & 0.5 & 1.6 & 1.0 & 0.4 & 0.5 & 0.2 & 0.3 & 0.4 & 0.4 & 0.5 & 0.5 & 0.3 & 0.3 & 0.3 & 0.2 \\
\hline Berlinia-type & 0.2 & 0.4 & 0.5 & 0.6 & 0.1 & 0.2 & 0.0 & 0.1 & 0.0 & 0.1 & 0.0 & 0.1 & 0.1 & 0.1 & 0.0 & 0.0 \\
\hline Rhamnaceae & 0.2 & 0.2 & 0.6 & 0.5 & 0.2 & 0.3 & 0.0 & 0.0 & 0.1 & 0.2 & 0.1 & 0.2 & 0.1 & 0.2 & 0.1 & 0.2 \\
\hline Pteris & 0.6 & 0.5 & 3.4 & 1.5 & 1.7 & 0.8 & 1.4 & 0.9 & 1.1 & 0.6 & 1.2 & 0.7 & 1.2 & 0.5 & 0.9 & 0.6 \\
\hline Hymenocardia & 1.2 & 0.8 & 0.1 & 0.2 & 0.2 & 0.3 & 0.0 & 0.1 & 0.0 & 0.1 & 0.0 & 0.1 & 0.0 & 0.1 & 0.0 & 0.0 \\
\hline
\end{tabular}

After $22 \mathrm{ka}$ sedimentation rates increase again to levels between 20 and $40 \mathrm{~cm} / \mathrm{ka}$ and jump to levels around $1 \mathrm{~m} / \mathrm{ka}$ shortly before $14 \mathrm{ka}$. We associate the strong increase in sedimentation rates with the rapid sea-level rise during Meltwater Pulse 1a dated between 14.6-14.3 ka (Fairbanks, 1989; Hanebuth et al., 2000). The levels of high sedimentation rates between 8 and 3 mbsf (14-9 ka) shows raised Rhizophora pollen percentages. This increased relative abundance of mangrove pollen comes together with increased amounts of other mangrove materials and is interpreted as sedimentation of eroded mangrove peat (Kim et al., 2005). Sedimentation levels remain high until $9 \mathrm{ka}$, when they drop again to levels between 25 and $40 \mathrm{~cm} / \mathrm{ka}$.

Thus the history of sea-level change at ODP Site 1078 as reconstructed with our age model fits well into the global picture, which makes us more confident about the age model itself.

\section{Results}

Alkenone-derived SSTs showed a typical glacial-interglacial warming trend, ranging from $21^{\circ}$ to $24^{\circ} \mathrm{C}$ over the last $30 \mathrm{ka}$ (Fig. 4). During the glacial period, alkenone-derived SSTs varied between $21^{\circ}$ and $23^{\circ} \mathrm{C}$ and decreased to the lowest value of $20.9^{\circ} \mathrm{C}$ at $16.3 \mathrm{cal} \mathrm{ka}$ during Heinrich Event 1 . Afterwards, alkenone-derived SSTs increased towards the Holocene, showing a warm period during the Younger Dryas. During the Holocene, alkenone-derived SSTs continued to increase to a core-top value of $24.9^{\circ} \mathrm{C}$ with a slight cooling around $5 \mathrm{cal} \mathrm{ka}$.

Based on the relative abundance of the most conclusive pollen taxa, seven pollen zones (PZ) have been distinguished. In this section, each zone is briefly characterised. Average percentage values per pollen zone are given for selected pollen taxa in Table 2. Percentages of groups and selected pollen taxa are given in Figs. 5-7. Appendix A lists the pollen taxa within each group. 


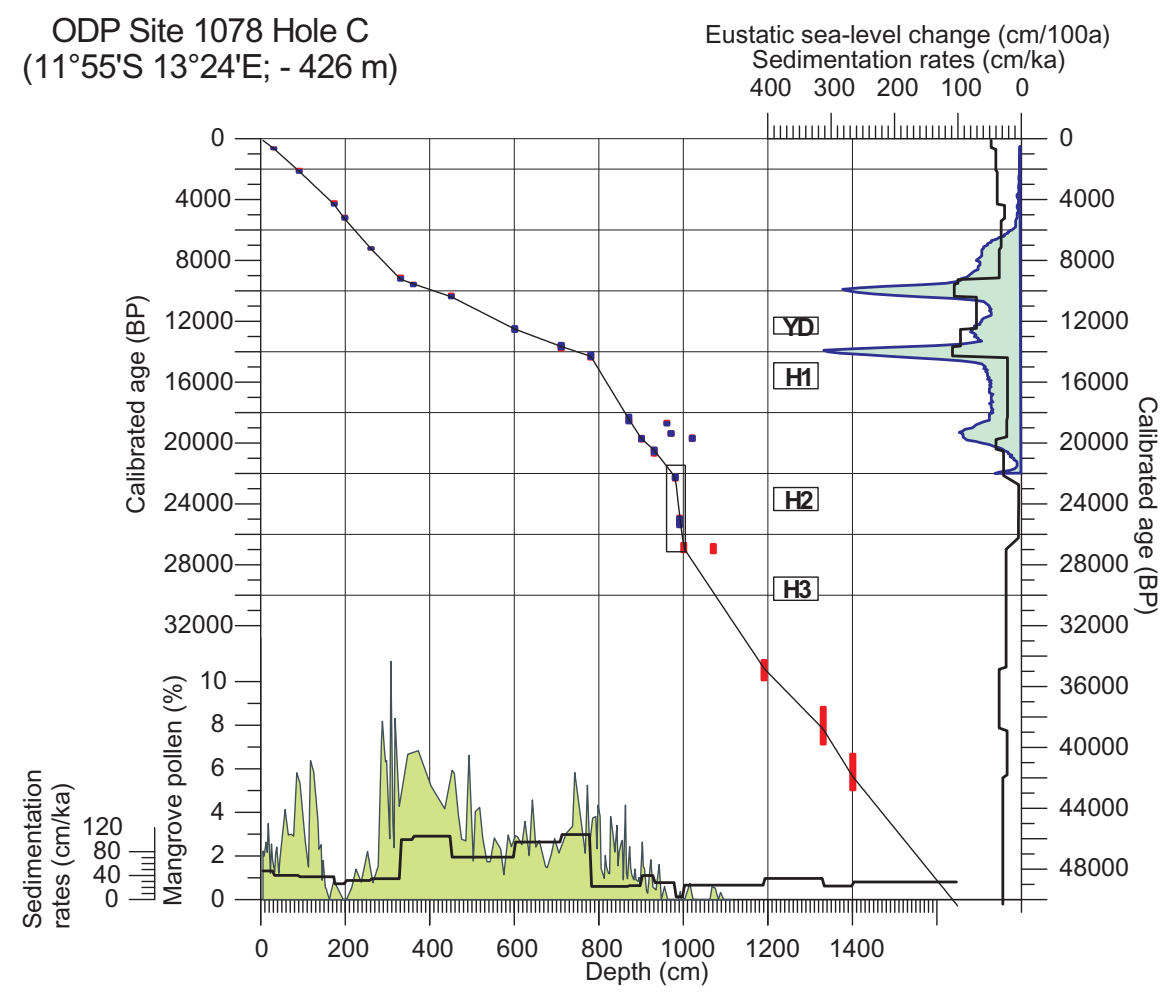

Fig. 3. Age model for ODP Hole 1078C (Kim et al., 2003; Rühlemann et al., 2004; Mulitza, personal communication, 2007). Denoted in blue are the age ranges calibrated with Calib using the marine04 calibration set (Hughen et al., 2004). Denoted in red are the age ranges calibrated after Fairbanks et al. (2005). Bottom shaded curve and left axis, pollen percent of Rhizophora (mangrove tree); bottom line and far left axis, sedimentation rates against depth; right shaded curve and upper axis, eustatic sea-level change after Fleming et al. (1998); right line and upper axis, sedimentation rates against age. YD, Younger Dryas; H1, H2, H3, Heinrich Events 1, 2, 3, respectively.

PZ 1: 25 samples between 11.16 (lowermost sample analysed) and $9.70 \mathrm{~m}$, dated between $31.7-21.9 \mathrm{ka}$. The record is poor between 9.99 and $9.81 \mathrm{~m}(26.3-22.4 \mathrm{ka})$, but not systematically different from the rest of the zone (see Table 2). Radiocarbon dates indicate very low sedimentation rates $(\sim 4 \mathrm{~cm} / \mathrm{ka})$ for this part of the zone. Maximum percentages of the mountain elements including pollen of Ericaceae, Myrica and Ilex cf. mitis, as well as spores of the fern Anemia and liverworts (Phaeoceros, Anthoceros) are found. High pollen percentages of Asteroideae, Stoebe-type, Poaceae, and other desert elements, e.g. Tribulus occur as well as raised percentages of Brachystegia.

PZ 2: 19 samples between $9.70-8.80 \mathrm{~m}$, dated between $21.9-18.8 \mathrm{ka}$. Gradual increase in the pollen concentration (Fig. 4) and a decline in percentages of desert and mountain elements are found. Myrica percentages are still relatively high. First rise in Rhizophora pollen percentages. Increase in percentages of Podocarpus and rain forest elements including Mallotus-type.

PZ 3: 23 samples between $8.80-8.02 \mathrm{~m}$, dated between 18.8-15.4 ka. Maximum Podocarpus percentages occur parallel to a minimum in sea surface temperatures as inferred from alkenones (Fig. 4: Kim et al., 2003). Of the rain forest elements only percentages of Mallotus-type and Tetrorchidium are raised. Rhizophora percentages also increase.

PZ 4: 43 samples between 8.02-4.20 m, dated between 15.4-10.0 ka. Pollen accumulation rates are dominated by the sedimentation rates (Fig. 4). Increase of pollen percentages of Uapaca and Brachystegia and the sum of Miombo elements. Rain forest percentages are relatively high and so are the values for a number of constituents: Tetrorchidium, Lophira, Celtis, and Alchornea. Rhizophora percentages also rise (Fig. 3), parallel to the global eustatic sea-level curve (Fleming et al., 1998).

PZ 5: 15 samples between $4.20-2.80 \mathrm{~m}$, dated between 10.0-7.8 ka. Percentages of Olea decrease, those of Miombo elements including Brachystegia and Uapaca are high, percentages of dry forest with Burkea-type increase, and percentages of rain forest elements decline with the exception of Alchornea. High percentages of Tarchonanthus/Artemisia afra also occur. Rhizophora and Cyperaceae percentages are maximal between 9-8 ka. Protea pollen occur shortly before $8 \mathrm{ka}$, when also Poaceae and Cyperaceae percentages are enhanced. Pollen concentrations are high and exceed on average $10^{4}$ grains per $\mathrm{ml}$. 


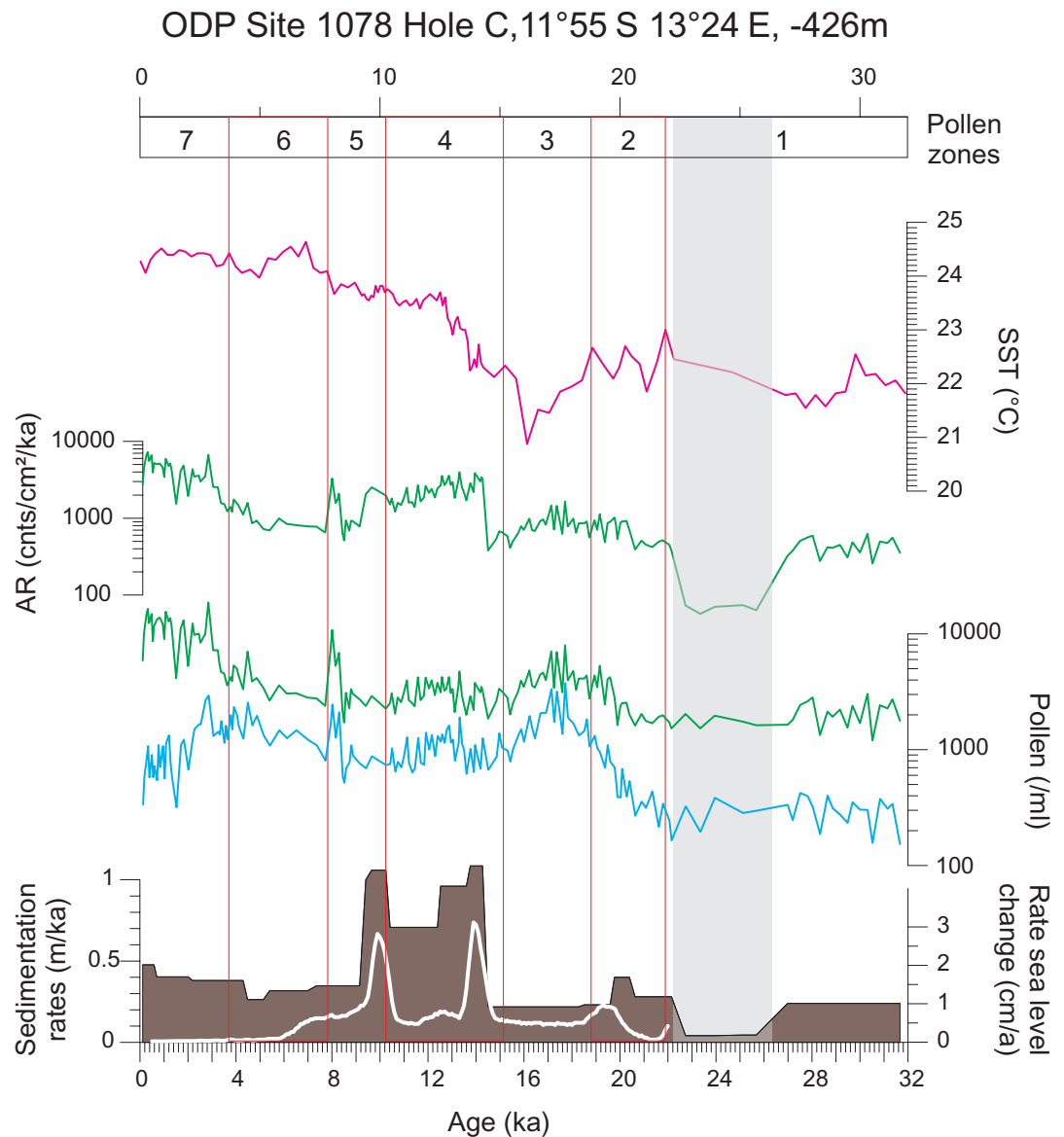

Fig. 4. From top to bottom. Pollen zones. Alkenone based sea surface temperatures (red line, upper right axis). Accumulation rates of total pollen per $\mathrm{cm}^{2}$ and $\mathrm{ka}$ (green line, upper left axis). Total pollen concentration (green line) and Podocarpus pollen concentration (blue line) per $\mathrm{ml}$ sediment (middle right axis). Sedimentation rates in $\mathrm{m}$ per ka (shaded, lower left axis) and rates of sea-level change (line, lower right axis) after Fleming et al. (1998).

PZ 6: 17 samples between 2.80-1.50 m, dated between 7.8-3.7 ka. Maximum percentages are found for Podocarpus, Miombo elements including Brachystegia, Afzelia, Berlinia-type, and Uapaca. Furthermore percentages of Rhamnaceae pollen (small pollen grains probably from $\mathrm{Zizi}$ phus) and Pteris spores are raised. From the dry forest elements Adansonia digitata and Lannea-type have higher values. Minimal Poaceae and Rhizophora percentages occur and Cyperaceae percentages are low. Pollen influx (accumulation rates) of Podocarpus and Miombo elements stay at the same level, but decline for Poaceae, Cyperaceae, Rhizophora, dry forest and rain forest elements.

PZ 7: 34 samples between 1.50-0 m, dated between $3.7 \mathrm{ka}$ and modern. Maximum percentages of Poaceae and Cyperaceae occur. Poaceae percentages reach their absolute maximum after $2 \mathrm{ka}$. Percentages are raised again for $R h i$ zophora and rain forest elements, in particular Alchornea and Elaeis guineensis. Also dry forest elements are better represented including Hymenocardia, Tarchonanthus/Artemisia afra, Protea, Burkea-type, and Combretaceae.

\section{Vegetation development in Angola in relation to cli- mate change}

ODP Site 1078 located on the lower shelf only $50 \mathrm{~km}$ from the shore is in an ideal position to collect pollen from the mainland. Directly east of the sampling site, the land rises steeply to elevations exceeding $1000 \mathrm{~m}$; highest peaks in the Huambe Mountains are just over $2000 \mathrm{~m}$. Fluvial transport of pollen is important, because the site is situated on the shelf in the vicinity of several rivers of which the Balombo River is the most important draining all ranges of the mountains. Because of the marine surface currents flowing southwards along the Angolan coast, discharge by the Balombo River and other smaller rivers nearby is more likely to contribute material than that of rivers such as the Cuhal do Hanha having their estuaries south of ODP Site 1078. The river collects pollen from a wide range of vegetation types passing at present through Afromontane vegetation, wetter Zambezian Miombo woodland and bushy Karoo-Namib shrubland along the coast (White, 1983). Almost $2^{\circ}$ north of the site, the 


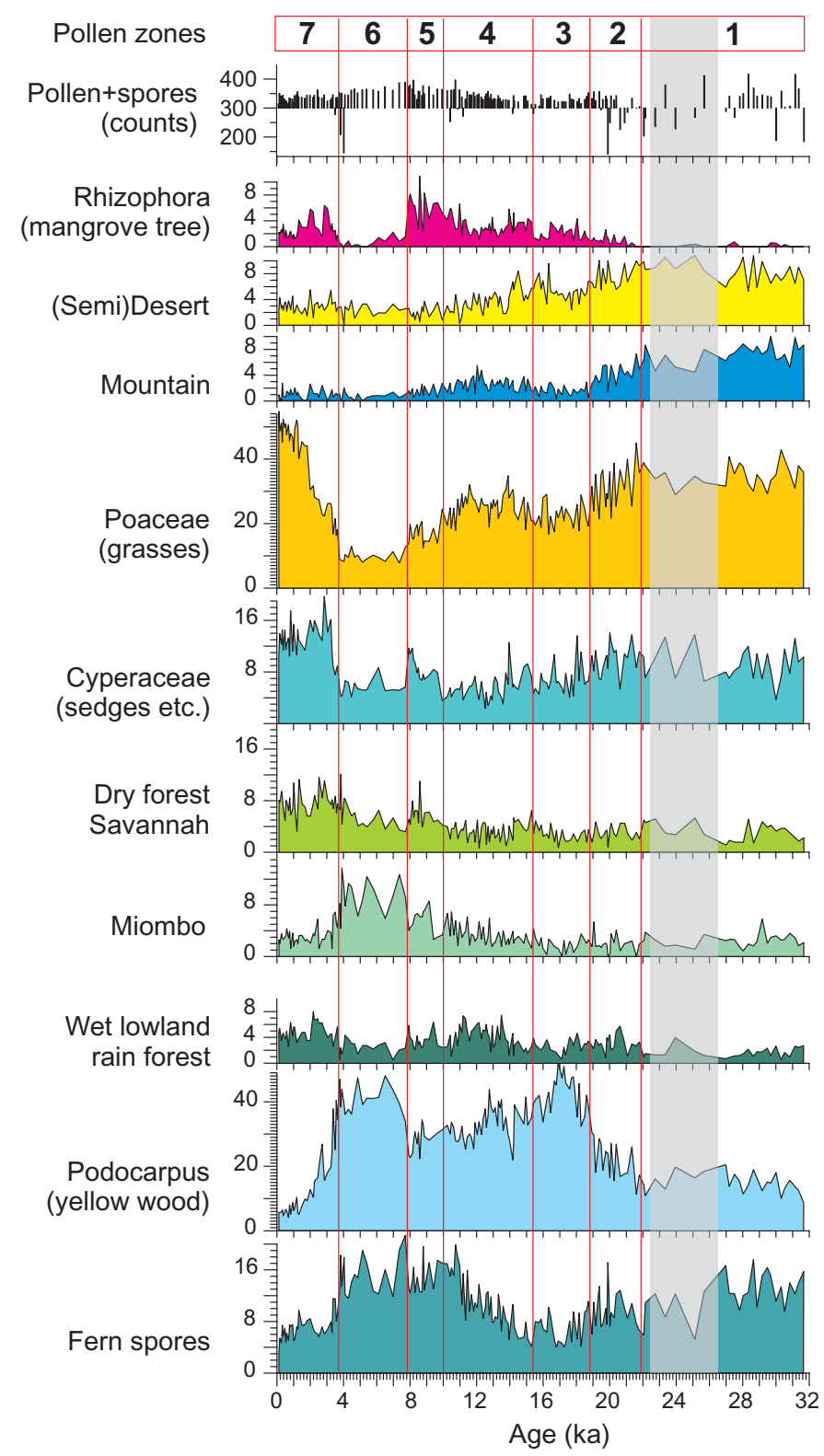

Fig. 5. Percentages of pollen taxa and groups (listed in appendix). Counts of total pollen and fern spores being the basis of the percent calculation are given on top. Shaded area indicates samples with low sedimentation rates and poor content.

southernmost mangrove swamps on the Atlantic coast of Africa are situated along the Longa River (Spalding et al., 1997). Southwest of ODP Site 1078, Moçamedes bushland and desert stretches along the coast of southern Angola and Namibia. Further inland in Angola, Mopane scrub woodlands occur. Aeolian transport of pollen to ODP Site 1078 is mainly expected during austral fall and winter when the lower troposphere flow is from the SE (Dupont and Wyputta, 2003). Source areas for fluvial and aeolian pollen largely overlap. An extensive discussion of pollen transport to and pollen distribution in marine sediments along the southwest African coast is given in Rommerskirchen et al. (2003), Dupont and Wyputta (2003), and Dupont et al. (2007).

\subsection{Glacial}

The lowermost part of the record, PZ1, covers the glacial between 31.7 and $21.9 \mathrm{ka}$. As discussed above, it includes the Last Glacial Maximum (defined as the period of lowest global sea-level). From the high pollen percentages of mountainous elements, including Ericaceae, Myrica and Ilex accompanied with high relative abundances of pollen of Poaceae and Asteraceae, we infer that open mountainous vegetation with heather species (Ericaceae), composites (Asteraceae), and grasses (Poaceae) was wide-spread (Fig. 6). Ericaceae and Ilex mitis are typical elements from the Afromontane vegetation (White, 1983). Palgrave 


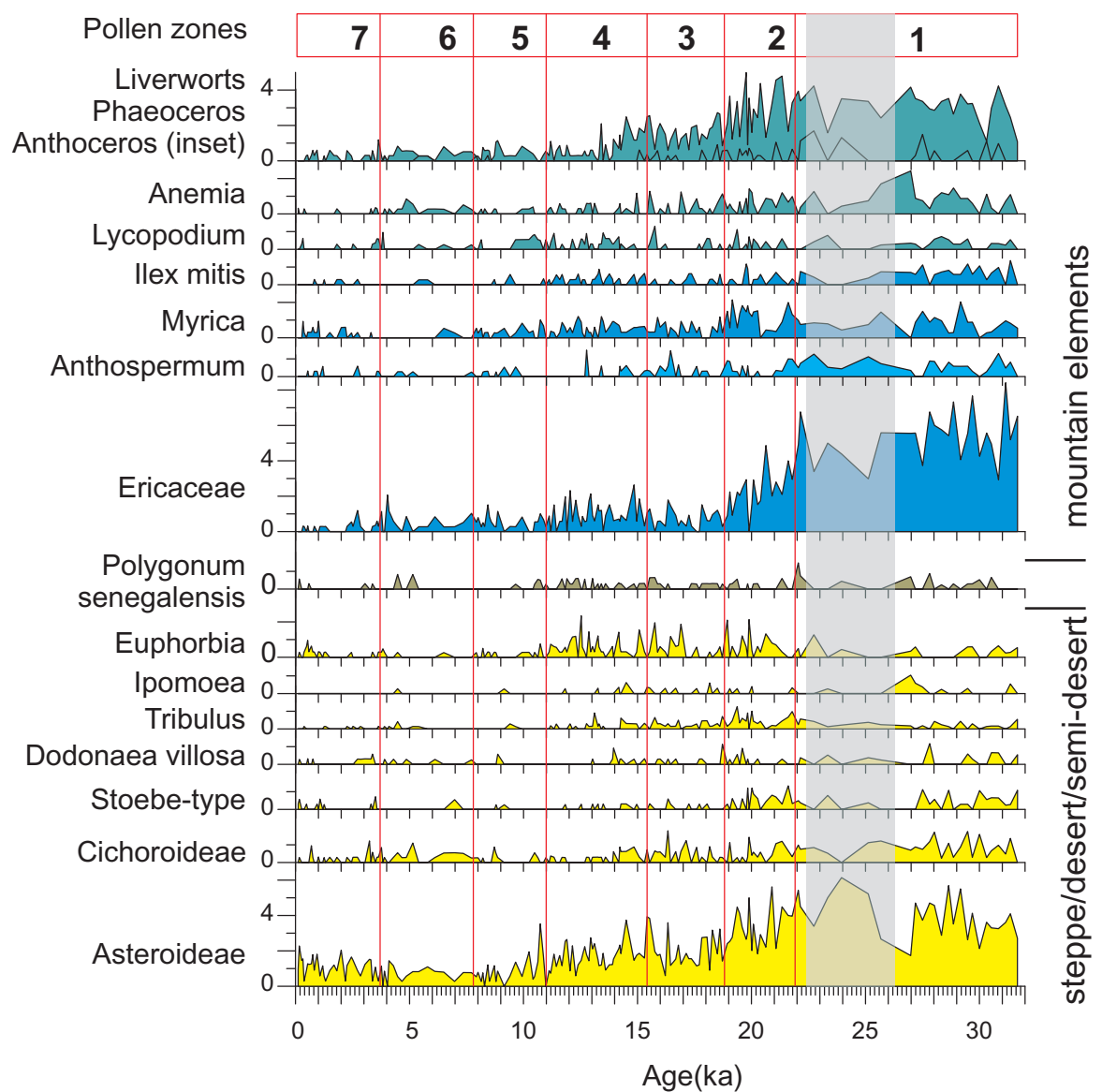

Fig. 6. Percentages of selected pollen taxa from desert, semi-desert, or open mountainous vegetation (pollen sums are given in Fig. 5). Shaded area denotes samples with low sedimentation rates and poor content.

(2002) mentions several Myrica species from mountain areas. Also Anthospermum species have been associated with ericaceous mountain vegetation (Scott, 1982). No pollen of Restionaceae has been found. We, therefore, do not expect to have Ericaceae pollen originating from southern source areas other than the regional mountains (Dupont and Behling, 2006).

Apart from the Afromontane vegetation, the existence of dry woodlands, probably at lower altitudes is suggested by the occurrence of pollen of Brachystegia and spores of Anemia. The Flora Zambesiaca (Schelpe, 1970) describes the present habitat of Anemia angolensis in the undergrowth of dry woodland at altitudes between 600-1525 m. Pollen from composites and grasses probably had their sources not only from Afromontane vegetation but from desert and semidesert vegetation along the coast, as well. Extension of desert and semi-desert is also indicated by the regular occurrence of Tribulus and Stoebe-type pollen. Is this extension a result of a northward shift of the Angola Benguela Front (ABF) and increased upwelling along the coast? Alkenone measurements indicate SSTs (Fig. 4) were around $22^{\circ} \mathrm{C}$ (Kim et al., 2003) 2 to 3 degrees lower than today. Increased upwelling, how- ever, should have lowered the SST below the general cooling of the glacial ocean, which is estimated at $4-5^{\circ} \mathrm{C}$ for the east equatorial Atlantic (Niebler et al., 2003). Comparison of several SST profiles with a coarser timely resolution between $5^{\circ}$ and $20^{\circ} \mathrm{S}$ did not indicate a shift of the ABF north of $12^{\circ} \mathrm{S}$ during the glacial (Schneider et al., 1995). Thus, there is little indication of upwelling of cooler intermediate waters.

The open mountainous vegetation and the expansion of desert and semi-desert suggest a cooler and drier climate in Angola during the glacial. Our data corroborate terrestrial mountain records, especially in east Africa, of an open glacial landscape covered with a grass- and ericaceous-rich vegetation, e.g. Sacred Lake at $0^{\circ} \mathrm{S} 37^{\circ} \mathrm{E}$ (Coetzee, 1967), and Kashiru at $3^{\circ} \mathrm{S} 30^{\circ} \mathrm{E}$ (Bonnefille and Riollet, 1988; Bonnefille and Chalié, 2000). However, in Congo at Ngamalaka Pond $\left(4^{\circ} \mathrm{S} 15^{\circ} \mathrm{E}\right)$ located at lower altitudes and nearer to the equator, no mountain elements were found (Elenga et al., 1994). Forest growth in the mountains might have been impeded by low temperatures at higher altitudes, dry conditions, and/or due to low glacial atmospheric carbon dioxide levels (Jolly and Haxeltine, 1997). 


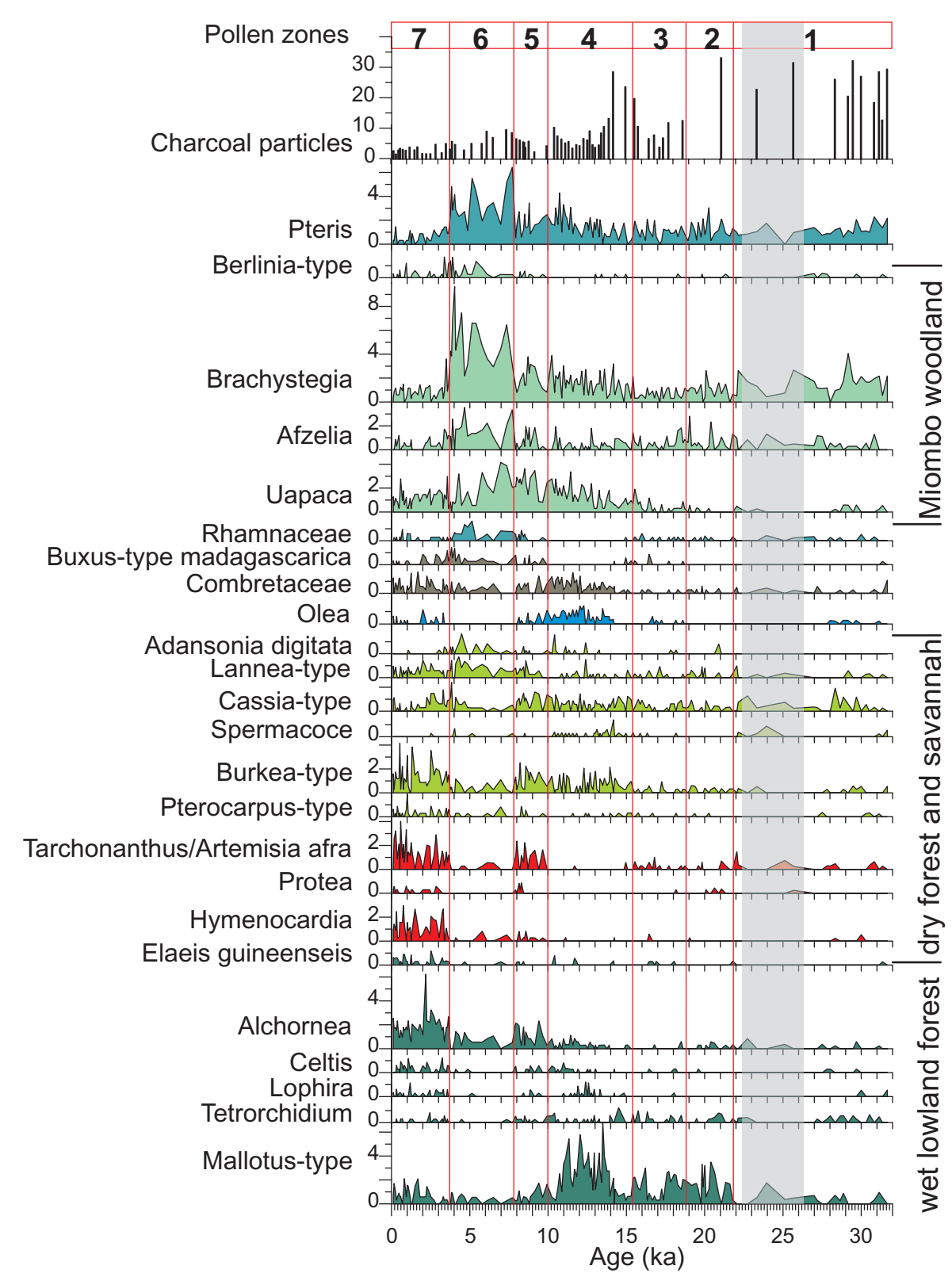

Fig. 7. Percentages of selected pollen taxa from rain forest, dry forest and woodland, and Miombo woodland (pollen sums are given in Fig. 5). Charcoal percentages are also expressed on the total of pollen and spores. Shaded area denotes samples with low sedimentation rates and poor content.

Between 21.9 and $18.8 \mathrm{ka}$, PZ2, the vegetation in Angola gradually changes. The relative abundance of pollen from open vegetation types (Afromontane and desert) declines, and tree pollen percentages of Podocarpus (Fig. 5) and Mallotus-type (Fig. 7) rise. Probably, Podocarpus trees were spreading in the mountains, while rainforest started to expand in the northern lowlands with pioneer trees such as Mallotus (Maley and Brenac, 1998). Other Afromontane trees such as Ilex mitis and Myrica are still present (Fig. 6). The gradual increase in pollen concentration (see Fig. 3) sug- gests higher terrestrial - probably fluvial - input. Change to warmer and more humid conditions after the glacial thus starts much earlier in Angola than in West Africa north of the equator as indicated by the Niger and Sanaga River discharge increasing not before 14-15 ka (Adegbie et al., 2003; Lezine and Cazet, 2005; Weldeab et al., 2007).

South of the equator, at the Bateke Plataeu in Congo around Ngamalake Pond $\left(4^{\circ} \mathrm{S}\right)$, humid forest elements invade an open landscape as early as $24 \mathrm{ka}$ (Elenga et al., 2004). Around $22 \mathrm{ka}$, contemporaneously with the Angolan 
January (austral summer) position of ITCZ (and CAB)

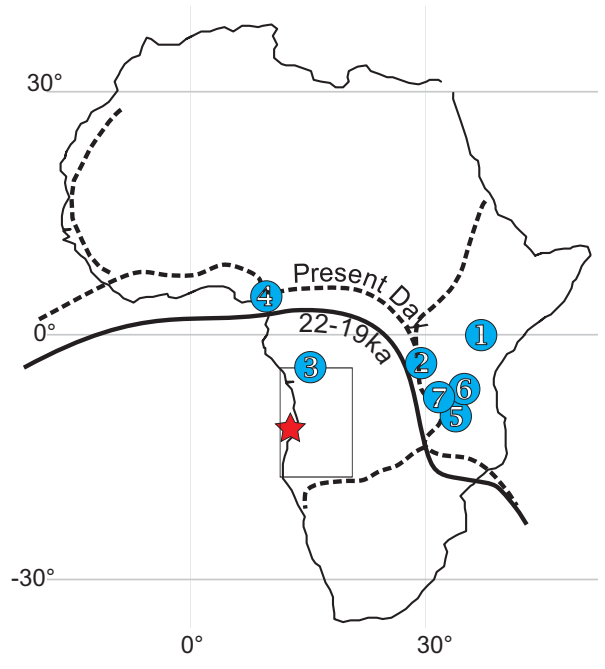

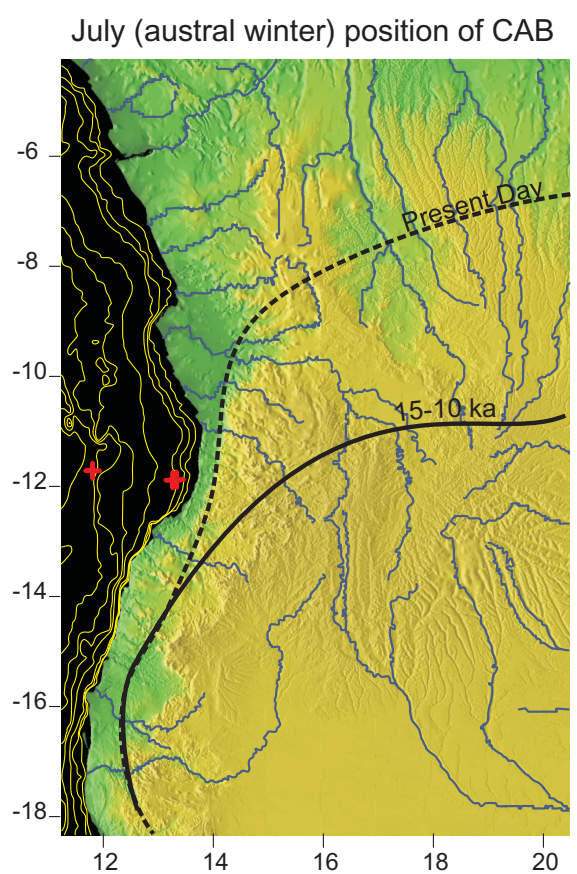

Fig. 8. Conceptual model of shifted average latitudinal positions of the Congo Air Boundary (CAB) and Intertropical Convergence Zone (ITCZ) during Deglaciation. Left, ITCZ January position for 22-19ka (line). Dashed line denotes the present-day average January position of the ITCZ system (Leroux 1983). Star shows the position of ODP Site 1078 and numbers the locations of published sites mentioned in the discusion. 1, Sacred Lake (Coetzee 1967); 2, Kashiru (Bonnefille and Riollet, 1988; Bonnefille and Chalié, 2000); 3, Ngamalaka Pond (Elenga et al., 1994); 4, Barombi Mbo (Maley and Brenac, 1998); 5, Lake Malawi (Johnson et al. 2004); 6, Lake Masoko (Vincens et al. 2007); 7, Lake Rukwa (Vincens et al., 2005). Box denotes the area shown in detail. Right, CAB July position for 15-10 ka (line) projected on the GLOBE topography (see Fig. 2). Dashed line shows the present-day average July position of the CAB (Leroux, 1983). Crosses denote the locations from left to right of core GeoB 1016 and ODP Sites 1079/1078, respectively.

sequence, the lake level of Lake Malawi $\left(10^{\circ} \mathrm{S} 34^{\circ} \mathrm{E}\right)$ rises after the glacial lowstand indicating increased precipitation in the East African mountains (Johnson et al., 2004). Furthermore, semi-deciduous forest elements became established around Lake Masoko $\left(9^{\circ} \mathrm{S} 34^{\circ} \mathrm{E}\right)$ just north of Lake Malawi suggesting the dry season became as short as 3 to 4 months (Vincens et al., 2007). Glacial woodland and bushland with Afromontane elements around Lake Rukwa $\left(8^{\circ} \mathrm{S} 33^{\circ} \mathrm{E}\right)$ in Tanzania, however, indicate that the climate was still rather cool and dry (Vincens et al., 2005).

Expansion of rain forest in the northern lowlands of Angola also suggests increased precipitation, which is possible if the winter migration of the $\mathrm{CAB}$ migrated less northwards than in the period before. Then the CAB position would remain sufficiently to the south to allow Atlantic rain penetrating during most of the year in the northern lowlands of Angola. The spread of forest between 22 and $19 \mathrm{ka}$ is too early to be an effect of rising carbon dioxide levels, because the $\mathrm{CO}_{2}$ rise after the glacial is dated by Monnin et al. (2001) between 17 and $15.4 \mathrm{ka}$. Moreover, the pollen diagram from Lake Barombi $\left(4^{\circ} \mathrm{N} 9^{\circ} \mathrm{E}\right)$ in Cameroon indicates an opening of the forest and increase of grasslands from ca. $24 \mathrm{ka}$ on $\left(2{ }^{14} \mathrm{C}\right.$ ka, Maley and Brenac, 1998). The development north and south of the equator proceeding in opposite directions would fit with a southern average position of the ITCZ coupled to a southern position of the CAB (Fig. 8). Our interpretation fits the study of Johnson et al. (2004) inferring a southern average position of the ITCZ between 23 and $19 \mathrm{ka}$ based on the increased productivity in Lake Malawi coupled to northerly winds over the lake.

\subsection{Deglaciation}

The pollen diagram for the period between 18.8 and $15.4 \mathrm{ka}$, PZ3, covering Heinrich Event 1, is dominated by Podocarpus (Fig. 5). Podocarpus trees produce much aerodynamically well-equipped pollen and are, therefore, overrepresented in the pollen record, especially when wind transport is important. Still, there are few other elements represented save for Mallotus and Tetrorchidium from the rain forest (Fig. 7). Thus, although rain forest remained present in the northern lowlands, Podocarpus forest might have been locally abundant in the mountains. Unfortunately, the marine record of Podocarpus for this period is not consistent, because a comparable Podocarpus pollen maximum is missing in the nearby core of GeoB1016 (location given in Fig. 2 left; Shi 
and Dupont, 1997), but present in core GIK16867 ( $\left.3^{\circ} \mathrm{S} 5^{\circ} \mathrm{E}\right)$ further north along the trajectory of the trade winds (Dupont et al. 1996). The terrestrial pollen records in Cameroon and Congo indicate a mixture of semi-deciduous forests and grasslands but neither an open savannah nor a Podocarpus forest (Elenga et al., 1994; Maley and Brenac, 1998; Elenga et al., 2004). Precipitation estimates based on deuterium of terrestrial plant waxes from a core off the Congo River mouth indicate minimal humidity in the Congo Basin (Schefuß et al., 2005).

During this period SSTs reach a minimum of $21^{\circ} \mathrm{C}$ and the temperature difference with data from a site located 5 degrees of latitude further south (GeoB1023) is minimal (Kim et al., 2003). Kim et al. concluded that because of the small SST difference between 12 and $17^{\circ} \mathrm{S}$, the SE trade winds must have been weak. During the same period, biomarker based annual temperature estimates for the Congo Basin indicate lowest temperatures of the past $25 \mathrm{ka}$ (Weijers et al., 2007). The low SSTs at $12^{\circ} \mathrm{S}$ suggest a northern position of the ABF, over or even north of the location of the site. The $\mathrm{CAB}$ took a northern position again, at least during austral summer. The associated SE trade winds probably reached further northward and might have brought more Podocarpus pollen grains with them to the site increasing the representation of Podocarpus both in absolute values (pollen concentration, Fig. 4) and relative ones (pollen percentages, Fig. 5). Another implication is that upwelling over the site intensified. This upwelling would have increased the reservoir effect in the radiocarbon dates and the material consequently might be several centuries younger than dated by our age model. If we assume a younger age of $15-18$ ka for this pollen zone, i.e. 4 to 8 centuries younger, it would still include the period of Heinrich Event 1.

According to our age model, sedimentation rates increase strongly to values around $1 \mathrm{~m} / \mathrm{ka}$ at $14.3 \mathrm{ka}$ which correlates with Meltwater Pulse 1a and global sea-level rise (Fairbanks, 1989; Hanebuth et al., 2000). Higher sedimentation rates increased the accumulation of all pollen types, but Rhizophora pollen from the mangroves is overrepresented (Fig. 5). A raised representation of mangroves both in relative pollen abundance and by biomarkers during this time is explained by erosion of coastal mangrove peat during transgression and sea-level rise (Kim et al., 2005).

After Heinrich Event 1, between 15.4 and $10.0 \mathrm{ka}$ (PZ4), the representation of the lowland rain forest becomes stronger. Not only pioneer trees such as Mallotus, Celtis, and Alchornea occurred, but also Tetrorchidium and Lophira, indicating increase and maturing of the forest. During this period - just before the Holocene - the lowland rain forest probably reached its southernmost extension (Fig. 7). Apart from the expansion of the lowland rain forest, elements from dry forest and woodlands, such as Burkea-type and Combretaceae, and from the Miombo woodlands, such as $U a$ paca and Brachystegia, are increasingly represented. The Podocarpus record goes slightly down and that of Olea rises indicating a change in the mountain forest composition. The Younger Dryas period is not distinguished as such in our pollen record, but part of a longer period of favourable conditions for forest growth.

Most African records show a first return to moister conditions after the glacial around $15 \mathrm{ka}$, or slightly later (e.g. Maley and Brenac, 1998; Gasse, 2000; Gasse and Van Campo, 2001; Barker et al., 2004; Lezine and Cazet, 2005). Deuterium based precipitation estimates are high between 15 and $12 \mathrm{ka}$ and low between 12 and $11 \mathrm{ka}$ (Schefuß et al., 2005). In the Congo Basin increased precipitation resulted subsequently (at $13.5 \mathrm{ka}$ ) in a large palaeo-discharge event (Marret et al., 2001). Interruption and return to arid conditions during the Younger Dryas period is clear in the records from north of the equator (e.g. Hoelzmann et al., 2004). South of the equator, Lake Malawi shows an increase of productivity during the Younger Dryas period interpreted as the effect of strong northerly winds over Lake Malawi connected to a southern position of the ITCZ (Johnson et al., 2004). The pollen record of Lake Masoko shows an abrupt and irreversible change in the flora of the Younger Dryas period suggesting the climate changed from a mild short (3-4 months) dry season to a distinctive dry period of no less than 5 to 6 months (Vincens et al., 2007). Some records from west southern Africa indicate wetter conditions that might be associated with the Younger Dryas (Shi et al., 2000). Others, from eastern South Africa, indicate cooler and possibly drier conditions (e.g. Scott, 1982; Holmgren et al., 2003) but many are inconclusive concerning the Younger Dryas period (Scott et al., 1995).

The strong development of the rain forest and the initial development of the woodlands in Angola suggest an early southward shifting of the $\mathrm{CAB}$ during winter and summer (Fig. 8). The summer latitude might have been comparable to those of today and the winter latitude might have been further to the south causing a southward shift of the area with more or less humid conditions all year round. SSTs rose strongly indicating that the $\mathrm{ABF}$, and with it the area of coastal upwelling, probably shifted poleward, south of the site. The large difference in SSTs between 12 and $17^{\circ} \mathrm{S}$ suggest strong trade winds, in particular during the Younger Dryas period (Kim et al., 2003).

\subsection{Holocene}

During the early Holocene, between 10.0 and $7.8 \mathrm{ka}$ (PZ5), dry forest and Miombo woodlands became increasingly important while rain forest elements retreated, but for the pioneer tree Alchornea (Fig. 7). Miombo woodland is nowadays the prevalent vegetation on well drained soils of the main plateau in Angola and other parts of the Zambezian region (White 1983). The woodlands are dominated by species of Brachystegia, often accompanied by Julbernardia or Isoberlinia (included in the Berlinia-type). Associates are Afzelia, Uapaca, and Pericopsis. Decline in the representation of 
most rain forest elements suggests a northward shift of the winter $\mathrm{CAB}$ more or less to its modern position. Mangrove peat erosion increased during Meltwater Pulse $1 \mathrm{~b}$ around $10 \mathrm{ka}$ (Flemming et al., 1998) and the high total pollen input afterwards is associated with more river discharge.

The occurrence of Tarchonanthus/Artemisia afra and Protea shortly before $8 \mathrm{ka}$ might indicate disturbance of dry forests vegetation (see below). Also the slight increase in the representation of Poaceae and Cyperaceae suggests a forest decline. This disturbance is contemporaneous with the " 8.2 ka" event, which has been recognised in equatorial West Africa as an intermittent period of reduced Sanaga discharge associated with a reduction of the West African Monsoon (Weldeab et al., 2007b).

Afterwards, forest composition changed at $7.8 \mathrm{ka}$. Until 3.7 ka (PZ6) Podocarpus dominates in the mountains and other mountainous elements, such as Olea, are not represented (Figs. 5, 7). The representation of grasses is minimal indicating that open vegetation had become rare (Fig. 6). Dry forests included Adansonia digitata and Lannea (Fig. 7). The high representation of Brachystegia, Afzelia, Berliniatype, and Uapaca suggests a large expansion of the Miombo woodland. However, pollen percentages of Rhamnaceae, probably Ziziphus, and spore percentages of Pteris are also raised, indicating increased swamp forest vegetation. Among the genus Brachystegia there is one species B. laurentii occurring in wetter types of the rain forest. Also among Afzelia, the rain forest species $A$. africana might be present, but its present-day occurrence in the Congolian rain forest is only north of the equator (White, 1983). The genus Uapaca includes rain forest species, as well. Thus, an alternative albeit less-likely explanation to the spreading of the Miombo woodland would be the expansion of wetter types of rain forest. In both interpretations, savannahs were replaced by closed forest.

At $3.7 \mathrm{ka}$, the vegetation drastically changed again. The occurrence of Rhizophora pollen grains (Fig. 5) during this period indicates marine transport from the north as the modern southernmost distribution of mangroves is along the River Longa ( $10^{\circ} \mathrm{S}$, Spalding et al., 1997). Supply of $R h i$ zophora pollen through erosion of older mangrove peat strata is implausible, because global sea-level did not rise much during this period.

Typical for the past $3.7 \mathrm{ka}$ (PZ7) is the dramatic increase in the representation of Cyperaceae and grasses (Fig. 5). After $2 \mathrm{ka}$, the relative abundance of Poaceae pollen is even higher than during glacial times. The increase in Cyperaceae pollen percentages might be a localised phenomenon, the increase in grass pollen percentages is more regional as it is found as well in GeoB1016, located further offshore on the lower continental slope at $3411 \mathrm{~m}$ water depth (Shi and Dupont, 1997; Dupont et al., 2007). We find the high representation of grasses associated with more forest elements but not with increased relative abundance of desert or mountain elements. We, therefore, infer a strong increase of the savan- nah. The modern savannah forest mosaic of northern Angola might have come into existence around two thousand years ago. The patchy character of the forests is underlined by the increased representation of light-loving trees such as $A l$ chornea and the oil palm, Elaeis guineensis (Fig. 7).

Other changes are found in the composition of the dry forest, in which Burkea, Hymenocardia (possibly H. acida), Protea, and Tarchonanthus (possibly T. camphoratus) and/or Artemisia afra must have been prominent (Fig. 7). The latter taxa are associated with fire. Tarchonanthus camphoratus regenerates very well after disturbance by cutting or fire (Kiruki and Njung'e, 2007), Artemisia afra often colonizes burnt areas in mountains (Beentje, 1994), Protea grows in mountainous grasslands that are burnt, and Hymenocardia acida is also fire hardy (White, 1983). However, there is no increase in the amount of charcoal particles relative to the amount of pollen and spores. The amount of charcoal particles relative to the pollen sum is especially high during the glacial (Fig. 7). The continuity of the charcoal record indicates that fire always played a role in the vegetation development. We can only explain the occurrence of more firehardy elements by assuming a change but not necessarily an increase in the fire regime that favoured these specific trees.

The development in Angola fits the general trend of a humid early and middle Holocene followed by a drier late Holocene (Marchant and Hooghiemstra, 2004). The savannah minimum and probably most humid phase in Angola from 7.8 to $3.6 \mathrm{ka}$ falls during the maximum northward extension of the Sahelian vegetation from 7.8 to $5.7 \mathrm{ka}$ (Hoelzmann et al., 2004) but lasts longer. The humid phase in Angola ended around the same time as the second of two aridification steps (around 6.7-5.5 ka and 4.0-3.6 ka) indicated by lake levels of the Sahara-Sahel region (Gasse, 2000). Only the first aridification step is recorded in the dust flux record of ODP Hole $658 \mathrm{C}$ as the end of the African Humid period (DeMenocal et al., 2000; Adkins et al., 2006). Also west equatorial pollen records and the deuterium record for the Congo Basin indicate a sharp drop in humidity around $3 \mathrm{ka}$, which favoured the opening of the forest and the spread of savannahs (Elenga et al., 2004; Schefuß et al., 2005). A reforestation after $1 \mathrm{ka}$ as suggested by the pollen records from Congolian sites (Vincens et al., 1999) is not found in our record. In East Africa Holocene precipitation levels became increasingly variable after $4 \mathrm{ka}$ and declined after 2 until $0.5 \mathrm{ka}$ (Bonnefille and Chalié, 2000). For southern Africa numerous proxies indicate a temperature optimum shortly before $7.5 \mathrm{ka}$ and increase in summer rainfall. Aridification set in soon after $5 \mathrm{ka}$ (Scott and Lee-Thorp, 2004).

Thus, the Holocene climatic changes proceed largely parallel in northern, southern and equatorial Africa. Important changes in the average position or latitudinal migration of the tropical frontal systems (ITCZ and CAB), however, should have caused changes in the opposite direction. It seems that these frontal systems were in place during the Holocene and that the aridification of the past 4 to 2 ka cannot be explained 
by a southward shift of the average position of the $\mathrm{CAB}$ and ITCZ over Africa.

We might look to other than climatic causes for the vegetation changes in Angola two thousand years ago. Yet, archaeological data are scarce. Along tributaries of the Congo River in the central Congo Basin earliest findings date between 400 and 100 BC (Wotzka, 1995). In Angola, the earliest known ceramics originate from a site close to Luanda, and are no older than the second century AD (Lanfranchi and Clist, 1991). In northern Namibia, early ceramics date back to the first centuries AD. These finds suggest an economy based on small cattle herding and hunting (Bostoen, 2007). Still, it seems difficult to conceive that small cattle herding and hunting would have an impact big enough to explain the environmental change recorded in the marine sediments. Moreover, the increase in savannah vegetation already started shortly after $4 \mathrm{ka}$, almost two millennia earlier than the earliest pottery findings in Angola. Much more corroborating terrestrial evidence is needed before human impact can be postulated as an important driver of the savannah increase and changes in forest composition around $0 \mathrm{BC}$.

\section{Conclusions}

The marine pollen record of ODP Hole $1078 \mathrm{C}$ provides a detailed history of the Angolan vegetation development since the last glacial, which we interpret as follows.

- From $31.7 \mathrm{ka}$ (the beginning of the record) until $21.9 \mathrm{ka}$ open mountainous vegetation with heather species, composites, and grasses was important, but dry woodlands also existed. Desert and semi-desert extended rather far to the north.

- Between 21.9 and 18.8 ka Podocarpus trees spread in the mountains, while rain forest started to expand in the northern lowlands.

- From 18.8 to 15.4 ka rain forest remained present in the northern lowlands and Podocarpus forest might have been locally abundant in the mountains.

- After 15.4 ka the Olea record indicates a change in the mountain forest composition. Until 10.0 ka rain forest was important, but woodland elements were also present.

- The Holocene started with dry forest and Miombo woodlands expanding while rain forest elements retreated.

- After a disturbance around 8 ka Podocarpus forest dominated between 7.8 and $3.7 \mathrm{ka}$. During this period, either Miombo woodland or wetter types of rain forest expanded and replaced open savannah vegetation.
- Savannahs became increasingly important after 3.7 and again after $2 \mathrm{ka}$. Forests probably became patchy growing light-loving and fire-hardy trees.

Glacial SSTs fluctuate around $22^{\circ} \mathrm{C}$ until $19 \mathrm{ka}$ and show a prominent minimum of ca. $21^{\circ} \mathrm{C}$ at $16 \mathrm{ka}$. From this minimum SSTs rise continuously to mid and late Holocene levels between 24 and $25^{\circ} \mathrm{C}$. During the past $7 \mathrm{ka}$, a slight cooling by half a degree occurred between 5 and $4 \mathrm{ka}$.

After the cool and dry climate of the last glacial the change to more humid conditions started very early in Angola $(22 \mathrm{ka})$. The early amelioration is probably related to the early warming on Antarctica. The $\mathrm{CAB}$ might have shifted to the south (Fig. 8).

Between 18.8 and 15.4 ka (around Heinrich Event 1), low SSTs indicate a northern position of the ABF implying permanent upwelling along the coast and strong SE trade winds. Conditions were cool but probably not arid. During this early stage there is a different development in Angola than in the Congo Basin or in West Africa where the climate was cold and dry.

After Heinrich Event 1, the climate in Angola became wetter and warmer and possibly even wetter than during most of the Holocene. No return to glacial conditions was found for the Younger Dryas period. The average position and the latitudinal migration of the CAB and ITCZ might have been further south than during the Holocene (Fig. 8).

During the early Holocene the average position of the $\mathrm{CAB}$ was probably already close to its present position and the modern West African monsoon system in place.

\section{Appendix A}

\section{Grouping of pollen types}

Steppe/desert/semi-desert

Acanthaceae (Barleria, Justicia/Monechma, Petalidium), Aizoaceae, Amaranthaceae (Gomphrena-type), Amaranthaceae/Chenopodiaceae, Arecaceae (Phoenix), Asteraceae (Atractylis-type, Asteroideae, Cichoroideae, Pentzia-type, Stoebe-type), Boraginaceae (Cordia, Heliotropium), Burseraceae (Boswellia), Campanulaceae, Capparaceae (Cadaba, Cleome, Maerua-type), Caryophyllaceae, Convolvulaceae (Convolvulus-type, Ipomoea-type, Merremia), Crassulaceae (Kalanchoe), Cucurbitaceae (Citrullus), Euphorbiaceae (Chrozophora, Euphorbia), Fabaceae (Crotalaria, Indigofera-type, Parkinsonia, Rhynchosia-type, Tephrosia), Geraniaceae (Pelargonium), Liliaceae (Aloe-type), Malvaceae, Neuradaceae, Nyctaginaceae (Boerhavia), Plantaginaceae (Plantago), Polygonaceae (Calligonum), Salvadoraceae (Salvadora persica), Sapindaceae (Dodonaea viscosa), Scrophulariaceae (Walafrida), Solanaceae (Solanum), Sterculiaceae (Hermannia, Hermannia strictatype), Thymelaeaceae, Tiliaceae (Corchorus), Verbenaceae 
(Phyla nodiflora), Welwitschiaceae (Welwitschia), Zygophyllaceae (Nitraria, Tribulus, Zygophyllum)

Dry forest and savannah

Acanthaceae (Blepharis-type, Hypoestes-type) Anacardiaceae (Lannea-type, Sclerocarya-type birrea), Annonaceae, Araliaceae (Cussonia), Arecaceae (Cocos nucifera), Asteraceae (Tarchonanthus/Artemisia afra-type), Balanitaceae (Balanites), Bignoniaceae (Spathodea), Bombacaceae (Adansonia, Bombax, Ceiba pentandra), Buxaceae (Buxus madagascarica-type) Caesalpiniaceae (Bauhiniatype, Burkea, Cassia-type, Colophospermum mopane, Detarium, Dialium-type, Piliostigma), Capparaceae (Boscia-type, Capparis), Celastraceae (Maytenus-type), Clusiaceae (Garcinia), Conneraceae (Cnestis-type), Cucurbitaceae (Coccinia, Luffa), Euphorbiaceae (Acalypha, Antidesma, Bridelia, Croton-type, Hymenocardia, Securinega), Fabaceae (Baphia-type, Dalbergia, Erythrina, Ormocarpum, Papilionoideae p.p., Pterocarpus-type, Sesbania-type), Flacourtiaceae (Flacourtia), Linaceae (Hugonia), Loganiaceae (Strychnos), Malphigiaceae (Triapsis), Meliaceae (Pseudocedrela), Mimosaceae (Mimosa pigra), Myrsinaceae (Maesa lanceolata-type), Nyctaginaceae p.p., Olacaceae (Olax), Oleaceae (Jasminum/Schrebera), Proteaceae (Protea), Ranunculaceae (Clematis-type), Rubiaceae (Canthium, Kohautia, Psydrax-type subcordata, Rubiaceae monade, Rytigynia-type, Spermacoce-type, Stipularia africana, Tarenna), Rutaceae (Teclea, Zanthoxylum), Sapindaceae (Allophylus, Cardiospermum), Sapotaceae (Butyrospermum), Sterculiaceae (Dombeya, Sterculia-type), Tiliaceae (Grewia)

Miombo woodland

Caesalpiniaceae (Afzelia, Berlinia-type, Brachystegia, Paramacrolobium), Euphorbiaceae (Uapaca), Fabaceae (Pericopsis)

Mountain elements

Aquifoliaceae (Ilex cf. I. mitis), Ericaceae, Geraniaceae (Geranium), Lamiaceae (Ocimum), Myricaceae (Myrica), Myrsinaceae (Myrsine africana), Oleaceae (Chionanthustype, Olea, Olea capensis), Podocarpaceae (Podocarpus), Rubiaceae (Anthospermum), Restionaceae, Sapotaceae (Chrysophyllum)

Wet lowland forest (rain forest)

Anacardiaceae (Sorindeia-type), Apocynaceae (Adenium, Funtumia-type), Arecaceae (Elaeis guineensis), Bignoniaceae (Stereospermum), Caesalpiniaceae (Daniellia-type, Duparquetia orchidacea, Mezoneurontype, Tamarindus/Cryptosepalum, Tessmannia), Celastraceae/Hippocrateaceae, Euphorbiaceae (Alchornea,
Klaineanthus, Mallotus-type, Martretia, Phyllanthus, Tetrorchidium), Icacinaceae (Iodes), Leeaceae (Leea), Loranthaceae (Tapinanthus-type), Meliaceae (Khaya-type, Manilkara), Mimosaceae (Entada-type, Pentaclethra), Moraceae p.p., (Bosqueia), Myristicaceae (Pycnanthus), Myrtaceae (Sysygium), Ochnaceae (Lophira, Sauvagesia), Araliaceae (Schefflera), Rubiaceae (Coffea-type, Crossopteryx, Cuviera, Gaertnera, Ixora-type, Morinda, Mussaenda, Psydrax-type parvifora, Sabicea, Sherbournea), Sapindaceae (Blighia-type), Sterculiaceae (Cola cordifolia, Cola nitida-type, Melochia), Ulmaceae (Celtis, Holoptelea), Urticaceae, Vitaceae (Cissus)

Swamps

Acanthaceae (Hygrophila-type), Agavaceae (Dracaena), Alismataceae (Alisma plantago-aquatica), Arecaceae (Borassus-type, Hyphaene-type, Raphia-type), Bignoniaceae (Kigelia-type), Burseraceae (Canarium), Caesalpiniaceae (Monopetalanthus-type), Clusiaceae/Guttiferae (Symphonia globulifera), Dispacaceae (Cephalaria), Droseraceae (Drosera), Euphorbiaceae (Macaranga), Fabaceae (Aeschynomene), Halorrhagaceae (Myriophyllum), Irvingiaceae (Irvingia), Meliaceae (Trichilia), Mimosaceae (Pseudoprosopis), Nymphaeaceae (Nymphaea), Onagraceae (Ludwigia), Passifloraceae (Adenia), Potamogetaceae (Potamogeton), Rhamnaceae, Rubiaceae (Gardenia, Psychotria), Salicaceae (Salix), Sapindaceae (Aporrhiza), Typhaceae (Typha angustifolia-type, Typha latifolia), Utriculariaceae (Utricularia), Xyridaceae (Xyris)

Acknowledgements. We thank Irina Nickeleit, Oliver Lackmann, and Eric Ehlers for their help with the preparation of the samples. We are indepted to Stefan Mulitza who provided the unpublished radiocarbon dates. Annie Vincens and Guillaume Buchet helped to identify the pollen of Buxus-type madagascarica. We thank Francoise Chalié and an anonymous referee for their constructive reviews. Financial support was given by the Deutsche Forschungsgemeinschaft (DFG). Data are available in PANGAEA.

Edited by: C. Hatté

\section{References}

Adegbie, A. T., Schneider, R. R., Röhl, U., and Wefer, G.: Glacial millennial-scale fluctuations in central African precipitation recorded in terrigenous sediment supply and freshwater signals offshore Cameroon, Palaeogeogr. Palaeocl., 197, 323-333, 2003.

Adkins, J., DeMenocal, P., and Eshel, G.: The "African humid period" and the record of marine upwelling from excess ${ }^{230} \mathrm{Th}$ in Ocean Drilling Program Hole 658C, Paleoceanography, 21(PA4203), 1-14, 2006.

Barker, P., Talbot, M. R., Street-Perrot, F. A., Marret, F., Scourse, J., and Odada, E.: Late Quaternary climatic variability in intertropical Africa, in: Past Climate Variability through Europe and Africa, Springer, Dordrecht, The Netherlands, 118-138, 2004. 
Bartholome, E., Belward, A. S., Achard, F., Bartalev, S., CarmonaMoreno, C., Eva, H., Fritz, S., Gregoire, J.-M., Mayaux, P., and Stibig H.-J.: GLC2000: Global Land Cover mapping for the year 2000, http://www-gem.jrc.it/glc2000/, European Commission, 2002.

Beentje, H.: Kenya trees, shrubs and lianas, National Museum of Kenya, Nairobi, Kenya, 1994.

Bonnefille, R. and Chalié, F.: Pollen-inferred precipitation timeseries from equatorial mountains, Africa, the last $40 \mathrm{kyr} \mathrm{BP}$, Global Planet. Change, 26, 25-50, 2000.

Bonnefille, R. and Riollet, G.: Pollens des savanes d'Afrique orientale, Éditions du Centre National de la Recherche Scientifique, Paris, France, 1980.

Bonnefille, R. and Riollet, G.: The Kashiru pollen sequence (Burundi). Palaeoclimatic implications for the last 40,000 yr. B.P. in tropical Africa, Quaternary Res., 30, 19-35, 1988.

Bostoen, K.: Pots, words and the Bantu problem: on lexical reconstructionand early African history, J. Afr. Hist., 48, 173-199, 2007.

Butzin, M., Prange, M., and, Lohmann, G.: Radiocarbon simulations for the glacial ocean: the effects of wind stress, Southern Ocean sea ice and Heinrich events, Earth Planet. Sci. Lett., 235, 45-61, 2005.

Coetzee, J. A.: Pollen analytical studies in east and southern Africa, Palaeoecol. Afr., 3, 1-146, 1967.

DeMenocal, P. B., Ortiz, J., Guilderson, T., and Sarnthein, M.: Coherent high- and low-latitude climate variability during the Holocene warm period, Science, 288, 2198-2202, 2000.

Dupont, L. M. and Behling, H.: Land-sea linkages during deglaciation: High-resolution records from the eastern Atlantic off the coast of Namibia and Angola (ODP site 1078), Quatern. Int., 148, 19-28, 2006.

Dupont, L. M. and Wyputta, U.: Reconstructing pathways of aeolian pollen transport to the marine sediments along the coastline of SW Africa, Quaternary Sci. Rev., 22, 157-174, 2003.

Dupont, L. M., Shi, N., Jahns, S., and Marret, F.: Podocarpus in West Africa during the Late Pleistocene, Palaeoecol. Afr., 24, 85-101, 1996.

Dupont, L. M., Behling, H., Jahns, S., Marret, F., and Kim, J.H.: Variability in glacial and Holocene marine pollen records offshore from west southern Africa, Veg. Hist. Archaeobot., 16, 87-100, 2007.

Elenga, H., Schwartz, D., and Vincens, A.: Pollen evidence of late Quaternary vegetation and inferred climate changes in Congo, Palaeogeogr. Palaeocl., 109, 345-356, 1994.

Elenga, H., Maley, J., Vincens, A., and Farrera, I.: Palaeoenvironments, palaeoclimates and landscape development in Atlantic Equatorial Africa: a review of key sites covering the last $25 \mathrm{kyrs}$, Past Climate Variability through Europe and Africa, Springer, Dordrecht, The Netherlands, 181-198, 2004.

Fairbanks, R. G.: A 17,000-year glacio-eustatic sea level record: influence of glacial melting dates on the Younger Dryas event and deep ocean circulation, Nature, 342, 215-230, 1989.

Fairbanks, R. G., Mortlock, R. A., Chiu, T.-C., Cao, L., Kaplan, A., Guilderson, T. P., Fairbanks, T. W., Bloom, A. L., Grootes, P. M., and Nadeau, M.-J.: Radiocarbon calibration curve spanning 0 to 50,000 years BP based on paired ${ }^{230} \mathrm{Th} /{ }^{234} \mathrm{U} /{ }^{238} \mathrm{U}$ and ${ }^{14} \mathrm{C}$ dates on pristine corals, Quaternary Sci. Rev., 24, 1781-1796, 2005 .
Fleming, K., Johnston, P., Zwartz, D., Yokoyama, Y., Lambeck, K., and Chappell, J.: Refining the eustatic sea-level curve since the Last Glacial Maximum using far- and intermediate-field sites, Earth Planet. Sci. Lett., 163, 327-342, 1998.

Gasse, F.: Hydrological changes in the African tropics since the Last Glacial Maximum, Quaternary Sci. Rev., 19, 189-211, 2000.

Gasse, F. and Van Campo, E.: Late Quaternary environmental changes from a pollen and diatom record in the southern tropics (Lake Tritrivakely, Madagascar), Palaeogeogr. Palaeocl., 167, 287-308, 2001.

Hanebuth, T., Stattegger, K., and Grootes, P. M.: Rapid flooding of the Sunda shelf: A Late-Glacial sea level record, Science, 288, 1033-1035, 2000.

Hastings, D. A. and Dunbar, P. K.: Development \& assessment of the Global Land One-km Base Elevation digital elevation model (GLOBE), ISPRS Archives, 32, 218-221, 1998.

Hoelzmann, P., Gasse, F., Dupont, L.M., Salzmann, U., Staubwasser, M., Leuschner, D. C., and Sirocko, F.: Palaeoenvironmental changes in the arid and sub arid belt (Sahara-SahelArabian Peninsula) from $150 \mathrm{kyr}$ to present, Past Climate Variability through Europe and Africa, Springer, Dordrecht, The Netherlands, 219-256, 2004.

Hughen, K. A., Baillie, M. G. L., Bard, E., Bayliss, A., Beck, J. W., Bertrand, C., Blackwell, P. G., Buck, C. E., Burr, G., Cutler, K. B., Damon, P. E., Edwards, R. L., Fairbanks, R. G., Friedrich, M., Guilderson, T. P., Kromer, B., McCormac, F. G., Manning, S., Bronk Ramsey, C., Reimer, P. J., Reimer, R. W., Remmele, S., Southon, J. R., Stuiver, M., Talamo, S., Taylor, F. W., Van Der Plicht, J., and Weyhenmeyer, C. E.: Marine04 Marine radiocarbon age calibration, 26-0 ka BP, Radiocarbon, 46, 1059-1086, 2004.

Johnson, T. C., Brown, E. T., and McManus, J.: Diatom productivity in Northern Lake Malawi during the past 25000 years: implications for the position of the Intertropical Convergence Zone at millennial and shorter time scales, Past Climate Variability through Europe and Africa, Springer, Dordrecht, The Netherlands, 93-116, 2004.

Jolly, D. and Haxeltine, A.: Effect of low glacial atmospheric $\mathrm{CO}_{2}$ on tropical African montane vegetation, Science, 276, 786-788, 1997.

Kim, J.-H., Schneider, R. R., Müller, P. J., and Wefer, G: Interhemispheric comparison of deglacial sea-surface temperature patterns in Atlantic eastern boundary currents, Earth Planet. Sci. Lett., 194, 383-393, 2002.

Kim, J.-H., Schneider, R. R., Mulitza, S., and Müller, P. J.: Reconstruction of SE trade-wind intensity based on sea-surface temperature gradients in the Southeast Atlantic over the last $25 \mathrm{kyr}$, Geophys. Res. Lett., 30, 2144-2147, 2003.

Kim, J.-H., Dupont, L. M., Behling, H., and Versteegh, G. J. M.: Impacts of rapid sea-level rise on mangrove deposit erosion: application of taraxerol and Rhizophora records, J. Quaternary Sci., 20, 221-225, 2005.

Kiruki, H. and Njung'e, J.: Population density, structure and early growth characteristics of Tarchonanthus camphoratus ina woodland at Naivashe, Kenya, Afr. J. Ecol., 45, 31-40, 2007.

Köhler, E. and Brückner, P.: Die Pollenmorphologie der afrikanischen Buxus- und Notobuxus-Arten (Buxaceae) und ihre systematische Bedeutung, Grana, 21, 71-82, 1982. 
Lanfranchi, R. and Clist, B. (Eds.): Aux origines de l'Afrique centrale, Sepia, Paris, 1991.

Leroux, M.: Le climat de L'Afrique tropicale (Texte and atlas), Champion, Paris, France, 1983.

Lezine, A.-M. and Cazet, J.-P.: High-resolution pollen record from core KW31, Gulf of Guinea, documents the history of the lowland forests of West Equatorial Africa since $40000 \mathrm{yr}$ ago, Quaternary Res., 64, 432-443, 2005.

Maley, J. and Brenac, P.: Vegetation dynamics, palaeoenvironments and climatic changes in the forests of western Cameroon during the last 28000 years B.P., Rev. Palaeobot. Palyno., 99, 157-187, 1998.

Marchant, R. and Hooghiemstra, H.: Rapid environmental change in African and South American tropics around 4000 years before present: a review, Earth-Sci. Rev., 66, 217-260, 2004.

Marret, F., Scourse, J., Versteegh, G., Jansen, J. H. F., and Schneider, R.: Integrated marine and terrestrial evidence for abrupt Congo River palaeodischarge fluctuations during the last deglaciation, J. Quaternary Sci., 16, 761-766, 2001.

Monnin, E., Indermühle, A., Dällenbach, A., Flückiger, J., Stauffer, B., Stocker, T. F., Raynaud, D., and Barnola, J.-M.: Atmospheric $\mathrm{CO}_{2}$ concentrations over the last glacial termination, Science, 291, 112-114, 2001.

Müller, J. P., Kirst, G., Ruhland, G., Von Storch, I., Rosell-Melé, T.: Calibration of the alkenone paleotemperature index $U_{37}^{K^{\prime}}$ based on core-tops from the eastern South Atlantic and the global ocean $\left(60^{\circ} \mathrm{N}-60^{\circ} \mathrm{S}\right)$, Geochim. Cosmochim. Ac., 62, 17571772,1998

Nicholson, S. E.: The nature of rainfall variability over Africa on time scales of decades to millennia, Global Planet. Change, 26, 137-158, 2000.

Niebler, H. S., Arz, H. W., Donner, B., Mulitza, S., Pätzold, J., and Wefer, G.: Sea surface temperatures in the equatorial and South Atlantic Ocean during the Last Glacial Maximum (23-19 ka), Paleoceanography, 18, 1069-1080, 2003.

Palgrave, K. C.: Trees of Southern Africa, 3rd Ed., revised and updated, Struik, Cape Town, South Africa, 2002.

Peltier, W. R. and Fairbanks, R. G.: Global glacial ice volume and Last Glacial Maximum duration from an extended Barbados sea level record, Quaternary Sci. Rev., 25, 3322-3337, 2006.

Peterson, R. G. and Stramma, L.: Upper-level circulation in the South Atlantic Ocean, Prog. Oceanogr., 26, 1-73, 1991.

Prahl, F. G. and Wakeham, S. G.: Calibration of unsaturation patterns in long-chain ketone compositions for paleotemperature assessment, Nature, 330, 367-369, 1987.

Prahl, F. G., Muehlhausen, L. A., and Zahnle, D. L.: Further evaluation of long-chain alkenones as indicators of paleoceanographic conditions, Geochim. Cosmochim. Ac., 5, 2303-2310, 1988.

Rommerskirchen, R., Eglinton, G., Dupont, L., Güntner, U., Wenzel, C., and Rullkötter, J.: A North to South Transect of Holocene Southeast Atlantic Continental Margin Sediments: Relationship between Aerosol Transport and Compound-Specific $\delta^{13} \mathrm{C}$ Land Plant Biomarker and Pollen Records, Geochem. Geophy. Geosy., 4, 1101-1129, 2003.

Rühlemann, C., Mulitza, S., Lohmann, G., Paul, A., Prange, M., and Wefer, G.: Intermediate-depth warming in the tropical Atlantic related to weakened thermohaline circulation: Combining paleoclimate and modeling results for the last deglaciation, Paleoceanography, 19, PA1025, 1-10, 2004.
Schefuss, E., Schouten, S., and Schneider, R. R.: Climate controls on central African hydrology during the past 20000 years, Nature, 437, 1003-1006, 2005.

Schelpe, E. A. C. L. E.: Flora Zambesiaca, Pteridophyta, Royal Botanical Gardens, Kew, UK, 1970.

Schneider, R. R., Müller, P. J., and Ruhland, G.: Late Quaternary surface circulation in the east equatorial South Atlantic: Evidence from alkenone sea surface temperatures, Paleoceanography, 10, 197-219, 1995.

Schneider, R. R., Price, B., Müller, P.J, Kroon, D., and Alexander, I.: Monsoon related variations in Zaire (Congo) sediments load and influence of fluvial silicate supply on marine productivity in the east equatorial Atlantic, Paleoceanography, 12, 463-481, 1997.

Scott, L.: Late Quaternary fossil pollen grains from the Transvaal, South Africa, Rev. Palaeobot. Palyno., 36, 241-278, 1982a.

Scott, L.: A late Quaternary pollen record fromTransvaal bushveld, South Africa, Quaternary Res., 17, 339-370, 1982b.

Scott, L. and Tee-Thorp, J. A.: Holocene climatic trends and rythms in southern Africa, Past Climate Variability through Europe and Africa, Springer, Dordrecht, The Netherlands, 69-91, 2004.

Scott, L., Steenkamp, M., and Beaumont, P. B.: Palaeoenvironmental conditions in South Africa at the Pleistocene-Holocene transition, Quaternary Sci. Rev., 14, 937-947, 1995.

Shannon, V. and Nelson, G.: The Benguela: Large scale features and processes and system variability, The South Atlantic: Present and Past Circulation, Springer, Berlin, Germany, 163-210, 1996.

Shi, N. and Dupont, L. M.: Vegetation and climate history of SW Africa: a marine palynological record of the last 300000 years, Veg. Hist. Archaeobot., 6, 117-131, 1997.

Shi, N., Dupont, L. M., Beug, H.-J., and Schneider, R.: Correlation between vegetation in southwestern Africa and oceanic upwelling in the past 21000 years, Quaternary Res., 54, 72-80, 2000.

Sowunmi, M. A.: Pollen grains of Nigerian plants I, Woody species, Grana, 13, 145-186, 1973.

Sowunmi, M. A.: Pollen of Nigerian plants II, Woody species, Grana, 34, 39-44, 1995.

Spalding, M., Blasco, F., and Field, C.: World mangrove Atlas, The International Society for mangrove Ecosystems (ISME), Smith Settle, Otley, UK, 1997.

Stuiver, M. and Reimer, P. J.: Extended $14 \mathrm{C}$ database and revised CALIB 3.0 14C age calibration program, Radiocarbon, 35, 215 230, 1993.

Tyson, P. D.: Climate Change and Variability in Southern Africa, Oxford University Press, Cape Town, South Africa, 1986.

Vincens, A., Schwartz, D., Elenga, H., Reynaud-Farrera, I., Alexandre, A., Bertaux, J., Mariotti, A., Martin, L., Meunier, J. D., Nguetsop, F., Servant, M., Servant-Vildary, S., and Wirrmann, D., Forest response to climate changes in Atlantic Equatorial Africa during the last 4000 years BP and inheritance on the modern landscape, J. Biogeogr., 26, 879-885, 1999.

Vincens, A., Buchet, G., Williamson, D., and Taieb, M.: A 23000 yr pollen record from Lake Rukwa ( $8^{\circ} \mathrm{S}$, SW Tanzania): New data on vegetation dynamics and climate in Central Eastern Africa, Rev. Palaeobot. Palyno., 137, 147-162, 2005. 
Vincens, A., Garcin, Y., and Buchet, G.: Influence of rainfall seasonality on African lowland vegetation during the Late Quaternary: pollen evidence from Lake Masoko, Tanzania, J. Biogeogr., 34, 1274-1288, 2007.

Weldeab, S., Lea, D. W., Schneider, R. R. and Andersen, N.: 155000 Years of West African Monsoon and Ocean Thermal Evolution, Science, 316, 1303-1307, 2007.

Weldeab, S., Lea, D. W., Schneider, R. R., and Andersen, N.: Centennial scale climate instabilities in a wet early Holocene West African monsoon, Geophys. Res. Lett., 34, L24702, 1-6, 2007.
Wefer, G., Berger, W. H., Richter, C., and Shipboard Scientific Party: Proceedings Ocean Drilling Program, Initial Reports, 175, Ocean Drilling Program, College Station TX, 1998.

White, F.: The vegetation of Africa, Natural Resourses Research, 20, UNESCO, Paris, France, 1983.

Wotzka, H.-P.: Studien zur Archäologie des zentral-afrikanischen Regenwaldes, Africa Praehistorica, 6, Heinrich Barth Institut, Köln, 1995.

Ybert, J.-P.: Atlas de pollens de Cote d'Ivoire, ORSTOM, Paris, France, 1979. 